\title{
Konsep Penuaan Aktif di Malaysia: Satu Penelitian Awal
}

\section{(The Concept of Active Ageing of Malaysia: A Preliminary observation)}

\author{
Chai Ai Jing1 (iD), Harifah Mohd Noor²* \\ 1Pusat Pascasiswazah, Universiti Malaysia Sabah (UMS), Sabah, Malaysia. \\ Email: chaiaijing@gmail.com \\ ${ }^{2}$ Fakulti Sains Sosial dan Kemanusiaan, Universiti Malaysia Sabah (UMS), Sabah, Malaysia. \\ Email: harifah@ums.edu.my
}

\author{
KATA KUNCI: \\ Penuaan aktif \\ Warga emas \\ Dasar kerajaan \\ Aktif \\ Kesejahteraan hidup

\section{KEYWORDS:} \\ Active-ageing \\ The elderly \\ Government policy \\ Active \\ Well-being

\section{CORRESPONDING \\ AUTHOR (*): \\ Harifah Mohd Noor \\ (harifah@ums.edu.my)}

\section{CITATION:} \\ Chai, A. J., \& Harifah Mohd Noor. (2022). \\ Konsep Penuaan Aktif di Malaysia: Satu \\ Penelitian Awal. Malaysian Journal of Social \\ Sciences and Humanities (MJSSH), 7(2), \\ e001204. \\ https://doi.org/10.47405/mjssh.v7i2.1204
}

\begin{abstract}
ABSTRAK
Penuaan aktif adalah satu proses dimana mengoptimumkan peluang dalam mengakses kepada kesihatan, penglibatan diri dan keselamatan bagi meningkatkan kualiti hidup warga emas Penuaan aktif berlaku dalam seseorang individu atau sekumpulan penduduk yang menunjukkan potensi mereka dalam fizikal, sosial dan kesejahteraan mental. Mereka masih berupaya untuk melibatkan diri dalam komuniti setempat mengikut keperluan, keinginan, dan kepakaran mereka. Kajian ini dilakukan bertujuan untuk mengetahui aspek-aspek yang mempengaruhi penuaan aktif dalam kalangan warga emas akibat daripada peningkatan populasi warga emas dalam konteks Malaysia. Kajian ini meneliti sebanyak 12 buah artikel yang telah dipilih daripada pangkalan data Scopus, Science Direct, Google Scholar dan Academia yang diterbitkan antara tahun 2010 hingga 2021. Sorotan kajian berdasarkan ciri-ciri inclusion dan exclusion yang berpandukan skop kajian yang telah ditetapkan. Kajian ini terdapat tiga tema utama iaitu: (1) aspek yang mempengaruhi penuaan aktif; (2) perancangan polisi dan dasar kerajaan dalam mencapai penuaan aktif untuk mencapai kesejahteraan hidup dan; (3) cabaran dalam pencapaian penuaan aktif. Kesimpulannya, tinjauan bahan literatur ini dapat dijadikan bahan rujukan empirikal kepada perancang polisi dan penyelidik akan datang. Ini dapat membuka mata pihak berkepentingan dengan konsep penuaan aktif bagi membantu warga emas mengekalkan keaktifan mereka.
\end{abstract}

\section{ABSTRACT}

The active ageing process involves optimising opportunities for access to health, self-involvement, and safety in an ordered manner to improve seniors' quality of life after retirement in a career setting. Active ageing happens when a person or a group of individuals demonstrate their potential in physical, social, and lifelong mental well-being by engaging in the local community based on their needs, 
wants, and talents. This study aims to identify the factors that impact active ageing among the elderly as the senior population in Malaysia grows. This study looked at 12 Scopus, Science Direct, Google Scholar, and Academia published between 2010 and 2021. Literature review based on the inclusion and exclusion criteria directed by the study's scope. This study focuses on three key themes: (1) The factors that impact active ageing, (2) Government policy planning and policy in attaining active ageing to achieve well-being, (3) The barriers to achieving active ageing. To summarise, In conclusion, this literature review can be used as an empirical reference material for future policy planners and researchers. This can open the eyes of stakeholders with the concept of active aging to help the elderly to maintain their activity.

Sumbangan/Keaslian: Sumbangan artikel ini mampu memberi kefahaman kepada masyarakat tempatan mengenai konsep penuaan. Tinjauan literatur ini boleh dijadikan pencetus idea kepada perancang polisi agar dapat mengetahui keperluan warga emas agar boleh terus kekal aktif dalam sesuatu komuniti.

\section{Pengenalan}

Penuaan penduduk merupakan fenomena yang wujud di negara-negara membangun dan sedang membangun khususnya semakin ketara dalam konteks negara sedang membangun disebabkan perubahan arus modenisasi dan globalisasi. Peningkatan populasi warga emas telah mewujudkan pertimbangan perancang polisi untuk menyediakan pelan-pelan untuk meningkatkan sistem pengangkutan berorientasikan mobiliti dan aksesibiliti di bandar agar dapat membantu warga emas yang mempunyai keperluan pergerakan khususnya untuk memenuhi keperluan mobiliti warga emas dalam kegiatan harian. Warga emas memenuhi keperluan mobiliti mereka adalah untuk memperkasakan konsep penuaan aktif selepas persaraan. Mario Ulises et al. (2016) mendefinisikan penuaan sebagai "proses di mana perubahan struktur dan fungsional terkumpul dalam organisma sebagai hasil dari berlalunya waktu". Menurut Racio et al. (2013), penuaan adalah proses yang panjang di sepanjang jangka hayat individu bukan hanya disebabkan oleh usia dan genetik tetapi oleh interaksi antara keadaan sosiopersekitaran dengan peristiwa peribadi dan tingkah laku. Perubahan tersebut nyata sebagai puncak penurunan kesuburan dan fungsi fisiologi hingga waktu terakhir mereka berada di dunia ini.

Penuaan adalah proses menjadi tua dengan sejumlah peralihan dalam perjalanan hidup. Seiring bertambahnya usia, keupayaan fizikal dan mental warga emas menurun sementara itu mereka tidak dapat menguruskan hidup mereka sebaik yang mereka lakukan sebelumnya. Peralihan tersebut mungkin termasuk persaraan, penempatan semula, kematian pasangan atau rakan, sindrom geriatrik seperti lemah, penurunan aktiviti fizikal, masalah dengan ingatan dan sebagainya (Pandey, 2018). Fenomena ini telah menghasilkan implikasi kesihatan, sosial dan ekonomi yang mendalam terus menyumbangkan kepada cabaran yang signifikan dalam pengurusan keperluan warga emas dalam negara (Ahmad Bahuri et al., 2021). Warga tua mengalami kadar kekurangan keupayaan fizikal yang tinggi seperti pendengaran, penglihatan, kehilangan ingatan, inkontinensia kencing dan sakit sendi (Said, 2017; Bravo et al., 2012; Barca et al., 2011; Saraswat et al., 2020; De Luca et al., 2019). Penuaan merupakan cabaran pada 
masa yang sama menyediakan pelbagai peluang. Sekiranya warga tua aktif, dapat menikmati hidupnya tanpa menganggap dirinya sudah tua, lebih banyak kegiatan dalam hidupan harian dapat dilakukan bagi memanfaatkan masa lapangannya (Pandey, 2018). Moses dan Oluwole (2014), penuaan penduduk disebabkan beberapa faktor: (1) peningkatan populasi warga emas dalam kadar laju memberi cabaran negara-negara yang tidak bersedia dan (2) warga emas tidak mendapat struktur sokongan sosial dan kesihatan awam secara meluas terutamanya di negara sedang membangun.

\section{Sorotan Literatur}

\subsection{Penuaan Aktif}

Konsep penuaan aktif mula berkembang pada tahun 1990-an dengan penekanan pada hubungan antara aktiviti dan kesihatan (WHO, 1994). Pada bulan April 2002, perwakilan dari 159 negara bertemu di Madrid untuk mengadakan Perhimpunan Dunia PBB Kedua setelah perhimpunan pertama disambut di Vienna pada tahun 1992. Konsep penuaan telah dikemukan untuk pertama kalinya pada tahun 2002, diterima pakai oleh United Nation Madrid II International Plan of Action on Aging oleh Pertubuhan Kesihatan Sedunia (WHO). Penuaan aktif berlaku dalam kedua-dua konteks individu dan juga kumpulan komuniti. Ini dapat menyeru kesedaran orang awam bagi meneliti potensi warga emas dalam pencapaian kesejahteraan fizikal, sosial dan mental sepanjang hayat hidup dan mengambil bahagian dalam masyarakat mengikut keperluan, keinginan dan kemampuan khususnya bagi perancang polisi semasa penyediaan perlindungan, keselamatan dan penjagaan warga emas (WHO, 2002).

Menurut Erja et al. (2022) penuaan aktif merujuk kepada pendekatan hidup yang aktif selaras dengan matlamat, keupayaan dan peluang seseorang. Penuaan aktif individu merujuk kepada pendekatan aktif keseluruhan untuk kehidupan. Penuaan aktif individu merujuk kepada pendekatan aktif keseluruhan untuk kehidupan. Penuaan aktif meliputi kehendak, kebolehan, peluang dan tahap melakukan aktiviti. Individu yang mempunyai mobiliti kejiranan terhad memperoleh skor penuaan aktif yang lebih rendah. Skor penuaan aktif menurun sama tanpa mengira mobiliti kejiranan garis dasar. Penglibatan dalam beberapa aktiviti boleh dilakukan walaupun mobiliti kejiranan terhad. Wacana penuaan aktif memfokuskan pada pendorongan penyertaan warga emas dalam masyarakat di samping menekankan kecekapan dan pengetahuan yang dimiliki oleh warga emas (Daatland, 2005). Penuaan aktif adalah proses mengoptimumkan peluang untuk kesihatan, penglibatan diri dan keamanan untuk meningkatkan kualiti hidup seiring dengan pertambahan usia.

Konsep 'aktif ' didefinisikan oleh WHO (2002) adalah penyertaan secara berterusan dalam kegiatan sosial, ekonomi, budaya dan penyertaan tanggungjawab kewarganegaraan serta tidak hanya dirujuk kepada kemampuan fizikal seseorang dalam sumbangan tenaga kerja. Rantanen et al. (2019) menerangkan bahawa faktor yang menyumbang kepada penuaan aktif pada seseorang individu adalah aktiviti yang menitikberatkan matlamat, kapasiti fungsi dan peluang seseorang. Matlamat merujuk kepada apa yang mereka mahu lakukan; kapasiti fungsi adalah apa yang mereka mampu lakukan, peluang merujuk kepada peluang yang dirasakan untuk mendapatkan penghargaan. Rantanen et al. (2019) membuat hipotesis dimana penuaan aktif mampu mengekalkan atau menggalakkan kesejahteraan. Townsend (2007) menyatakan bahawa penuaan aktif menolak paradigma warga emas semestinya akan menghadapi masalah penurunan kualiti hidup akibat daripada keuzuran yang dihadapi dan menekankan 
bahawa peranan aktif warga emas yang dimiliki bagi teruskan kehidupan mereka dalam kalangan masyarakat. Ia menekankan keperluan untuk perbezaan antara tanggapan aktiviti dan pasif, di mana aktif melibatkan hidup mengikut peraturan sendiri menentang untuk "dinormalisasi" oleh masyarakat dalam kumpulan umur yang berlainan untuk mengelakkan pengecaman (Walker \& Foster, 2013).

Selain itu, Stenner et al. (2011) berpendapat bahawa penuaan aktif juga merangkumi keperluan untuk aktiviti yang dirancang untuk memastikan perlindungan, maruah, dan penjagaan warga emas. Kajiannya merangkumkan hasil analisis tematik ke atas 42 orang informan yang berbangsa British dimana umur berada pada 72 tahun dan ke atas. Penuaan aktif berkaitan dengan faktor fizikal, kognitif, psikologi dan sosial namun terdapat interaksi yang kompleks. Peningkatan dan penurunan penyertaan warga emas dalam aktiviti juga akan mempengaruhi penuaan aktif. Manakala, Hijas-Gómez et al. (2020) menyatakan bahawa persekitaran kejiranan mungkin penting kepada penuaan aktif secara fizikal, dan dengan itu membantu membentuk fungsi kognitif warga emas. Kajian ini lebih menumpu kepada lokasi warga emas melakukan senaman di luar rumah dan mengkaji adalah ketersediaan destinasi berada dalam persekitaran fizikal yang memudahkan warga emas. Hasil kajian menunjukkan ketersediaan pelbagai kemudahan seperti taman rekreasi dan premis perniagaan dikaitkan dengan tahap fungsi kognitif yang lebih tinggi.

Mendoza-Núñez et al. (2009) penuaan aktif pemberdayaan warga emas dalam bidang biologi, psikologi dan sosial. Makna pemberdayaan dalam konteks ini merujuk kepada kemampuan untuk membela hak diri dan bebas melakukan aktiviti yang diingini. Keupayaan kesihatan merupakan komponen penting dalam kalangan warga emas kerana penyakit kronik kerap berlaku pada usia tua seperti tekanan darah tinggi, diabetes, arthritis, osteoporosis, kemurungan, dan demensia. Penyakit kronik mendatangkan masalah kewangan untuk membebankan. Oleh hal yang sedemikian, pencegahan awal pada usia tua masih lagi diperlukan agar dapat mengekalkan keaktifan warga emas. Esther et al. (2016) berpendapat bahawa kawasan bandar mempunyai kepadatan penduduk yang tinggi. Ruang yang terbuka mendorong warga tua untuk meningkatkan interaksi sosial dan penuaan aktif. Walau bagaimanapun, perancangan dan reka bentuk kawasan lapang cenderung menekankan keperluan fizikal dan keselamatan warga tua, manakala keperluan sosial tidak dititikberatkan. Kajian ini amat penting untuk memberi lebih perhatian kepada keperluan sosial warga tua di kawasan bandar baru berbanding di kawasan pembangunan baharu. Ini kerana rangkaian sosial telah pun diwujudkan dalam kalangan masyarakat bandar di daerah lama. Hasil kajian Esther at al. (2016) manakala di kawasan pembangunan baharu, masyarakat masih belum membina ikatan dan semangat kemasyarakatan yang kukuh. Keperluan sosial termasuk penyertaan sosial kerana warga tua telah tinggal di kawasan ini selama bertahun-tahun, dan apa sahaja yang boleh mengubah kehidupan seharian mereka amat membimbangkan mereka. Perancangan kawasan lapang awam juga harus memastikan pemahaman akar sosiobudaya penduduk dan komuniti mereka, yang amat tertanam dalam kehidupan mereka seiring dengan usia mereka di daerah lama ini. Secara khususnya, akar umbi rakyat berkait rapat dengan elemen warisan budaya, kenangan dan ciri-ciri tempatan kawasan lama.

Dalam konteks Malaysia, mengikut Dasar Warga Emas Negara, penuaan aktif didefinisikan sebagai proses mengoptimumkan peluang dan penglibatan warga emas dalam keluarga dan masyarakat ke arah mendayaupayakan warga emas untuk meningkatkan kesejahteraan hidup (Kementerian Pembangunan Wanita, Keluarga dan 
Masyarakat, 2011). Penuaan aktif membolehkan warga emas melakukan sebarang aktiviti sama ada secara sendirian, bersama ahli keluarga atau masyarakat untuk kesejahteraan hidup mereka (Kementerian Kesihatan Malaysia, 2016). Penuaan aktif bermotifkan untuk mempertingkatkan kualiti hidup dan memanjangkan jangka hayat warga emas bagi mereka yang lemah, kurang upaya dan memerlukan penjagaan rapi. Mengekalkan autonomi dan kebebasan bagi seseorang yang semakin tua adalah matlamat utama bagi individu dan pembuat dasar kerana penuaan aktif ini melibatkan individu dan persekitaran sama ada ahli keluarga, jiran, rakan dan juga rakan sekerja. Inilah sebab kenapa penuaan aktif wujud dalam konteks secara individual ataupun secara kumpulan masyarakat kerana terdapat prinsip kebergantungan dan perpaduan dua hala antara generasi muda dan warga emas.

\subsection{Trend Peningkatan Warga emas di Malaysia}

Menurut Pala (2005), sejak Majlis Mesyuarat Dunia Pertubuhan Bangsa-Bangsa Bersatu memperkenalkan mengenai Penuaan pada tahun 1982 di Vienna, Malaysia telah menggunakan istilah definisi warga emas merujuk kepada individu yang berusia 60 tahun dan ke atas untuk membahaskan trend penuaan. Banci 2010 mencatatkan sejumlah 2.2 juta warga emas negara Malaysia yang bererti bahawa satu daripada setiap 13 orang di Malaysia pada hari ini berumur 60 tahun atau ke atas. Warga emas di Malaysia telah meningkat dari 5.4 peratus pada tahun 1970 kepada 7.9 peratus pada tahun 2010 (Jabatan Perangkaan Malaysia, 2018). Bilangan warga emas pada Banci 1990 dan 2000 menunjukkan peningkatan peratusan yang ketara (Jabatan Perangkaan Malaysia, 2018). Jadual 1 menunjukkan peningkatan populasi penuaan di Malaysia sejak tahun 1970. Komposisi warga emas di Malaysia dijangka berkembang lebih dua kali ganda dari tahun 1970 hingga 2020, iaitu 5.4 peratus hingga 11.1 peratus dan dijangka mencapai 19.8 peratus menjelang 2040. Dengan ini, Malaysia diramalkan akan menjadi negara tua pada tahun 2030 .

Jadual 1: Populasi warga emas di Malaysia (1970-2020)

\begin{tabular}{lll}
\hline Tahun & Jumlah warga tua ('000) & Peratusan (\%) \\
\hline 1970 & 591.6 & 5.4 \\
1980 & 759.6 & 5.5 \\
1991 & 1015.6 & 5.6 \\
2000 & 1451.2 & 6.2 \\
2010 & 2248.6 & 7.9 \\
2020 & 3749.0 & 11.1 \\
2030 & 5818.4 & 15.3 \\
2035 & 6956.6 & 17.4 \\
2040 & 8230.7 & 19.8 \\
\hline
\end{tabular}

Sumber: Jabatan Perangkaan Malaysia (2018)

\subsection{Faktor Peningkatan Populasi Warga Emas di Malaysia}

Menurut Nik Norliati (2018) faktor-faktor yang menyebabkan peningkatan populasi warga emas di Malaysia adalah peningkatan taraf pendidikan, penjagaan kesihatan, taraf pekerjaan dan jangka hayat individu manakala penurunan dari aspek kadar kelahiran dan kadar kematian (Rajah 1). Malaysia berada pada kedudukan ke-53 negara paling celik huruf seperti tersenarai dalam 'World's Most Literate Nations', menurut Menteri Pelancongan, Kebudayaan dan Alam Sekitar Sabah, Datuk Seri Masidi Manjun (Mystar, 2017). Forum Ekonomi Dunia (World Economic Forum) telah mengiktiraf Malaysia 
sebagai sebuah negara yang mempunyai tahap persaingan lebih baik dalam bidang pendidikan dari 141 buah negara di seluruh dunia pada tahun 2018. Berpandukan laporan terbaharunya, Malaysia menduduki kedudukan ke-19 lebih baik daripada negara maju seperti United Kingdom (UK), Perancis dan Jepun (Mystar, 2017). Menurut Ismail (2019), dalam perbandingan antara negara-negara Asia Tenggara, kualiti pendidikan Malaysia adalah pada kedudukan kedua selepas Singapura. Jelasnya, Malaysia mempunyai daya saing yang kompetitif dan progresif dalam bidang pendidikan. Selain itu, Malaysia juga merupakan negara pilihan dalam kalangan negara Arab dan Oceania untuk melanjutkan pelajaran ke peringkat pengajian tinggi.

Rajah 1: Faktor peningkatan warga emas di Malaysia

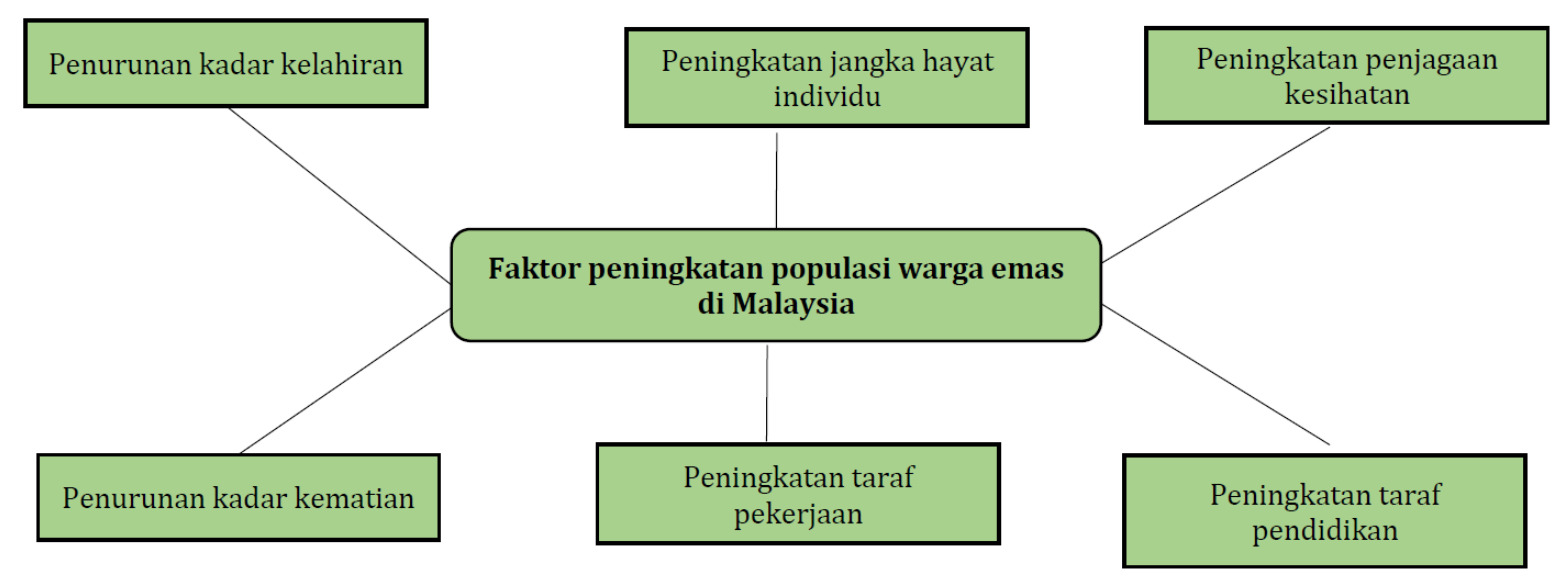

Sumber: Nik Norliati (2018)

Kerajaan Malaysia mengambil berat tentang tahap kesihatan penduduk dengan membekalkan perbelanjaan perubatan yang semakin tinggi dalam belanjawan tahunan. Menurut Kementerian Kesihatan Malaysia (2017) dalam Akaun Kesihatan Negara Malaysia, jumlah belanjawan tahunan untuk tujuan kesihatan adalah meningkat dari RM 8550 juta pada tahun 1997 kepada RM 57361 juta pada tahun 2017. Statistik tersebut telah menunjukkan bahawa peningkatan sebanyak lebih daripada enam kali ganda kerajaan melabur dalam sektor kesihatan bagi menyediakan pelbagai kemudahan infrastruktur dan hospitaliti dalam bidang perubatan. Dalam Rancangan Malaysia Ke-11, kerajaan telah menambah baik akses kepada perkhidmatan penjagaan kesihatan berkualiti dengan menaik taraf infrastruktur kesihatan, meningkatkan kapasiti personel kesihatan, menggalakkan amalan gaya hidup sihat, dan memperluas program rawatan pencegahan penyakit ke seluruh negara. Hasil daripada usaha kerajaan menambah baik sistem kesihatan ini dapat dilihat dalam peningkatan jangka hayat penduduk dan pengurangan jumlah kematian bayi dan ibu. Selain itu, Penubuhan Klinik 1 Malaysia dan Klinik Bergerak 1 Malaysia telah ditambah bagi meningkatkan akses kepada perkhidmatan penjagaan kesihatan yang mampu dibiayai oleh isi rumah berpendapatan rendah. Sehingga tahun 2014, sebanyak 307 Klinik 1 Malaysia telah diwujudkan di kawasan bandar dan 16 Klinik Bergerak 1 Malaysia telah beroperasi menggunakan bas dan bot di kawasan luar.

Peningkatan populasi warga emas juga disebabkan penurunan kadar kelahiran dan juga kadar kematian manakala peningkatan jangka hayat dalam kalangan populasi penduduk. Penurunan kadar kelahiran berkaitan rapat dengan kadar kesuburan wanita dalam negara. Jadual 2 menunjukkan statistik kadar kelahiran kasar, kadar kesuburan, 
kadar kematian semasa kelahiran dan juga jangkaan hayat hidup di Malaysia sejak tahun 1950 hingga 2021. Kadar kelahiran kasar menunjukkan trend penurunan di mana dari 43.8 orang bagi setiap 1000 orang (1950) kepada 16.3 orang bagi setiap 1000 orang (2021) dengan penurunan sebanyak 268 peratus. Hal ini sedemikian berkaitan dengan penurunan kadar kesuburan wanita pada peringkat masa yang sama, di mana kadar kesuburan wanita pada tahun 1950 adalah 6.4 orang anak bagi seorang wanita dan kadar ini telah turun sebanyak tiga kali ganda kepada 1.9 orang anak bagi setiap wanita pada tahun 2021. Penurunan kadar kelahiran boleh dikaitkan dengan pelbagai faktor seperti peningkatan kos sara hidup, perancangan keluarga awal, penglibatan wanita dalam pelbagai kerjaya dan sebagainya. Pada tahun 2016, kadar penyertaan tenaga buruh wanita yang telah dilaporkan meningkat kepada 53.9 peratus berbanding 49.5 peratus pada tahun 2012 (Kementerian Pembangunan Wanita, Keluarga dan Masyarakat, 2017). Nur Syakiran et al. (2017) menyatakan bahawa arus modenisasi banyak mengubah struktur keluarga di Malaysia sehingga perancangan masa hadapan dilihat penting dalam kehidupan. Punca peningkatan jangka hayat adalah sistem perkhidmatan kesihatan yang baik, selain kesedaran penduduk terhadap kepentingan menjaga kesihatan yang semakin meningkat (Lai, 2020).

Jadual 2: Kadar kelahiran kasar, kadar kesuburan, kadar kematian ketika lahir dan jangka hayat penduduk (1950-2021)

\begin{tabular}{lllll}
\hline Tahun & $\begin{array}{l}\text { Kadar kelahiran } \\
\text { kasar (per 1000 } \\
\text { orang) }\end{array}$ & $\begin{array}{l}\text { Kadar kesuburan } \\
\text { (anak bagi setiap } \\
\text { wanita) }\end{array}$ & $\begin{array}{l}\text { Kadar kematian } \\
\text { ketika lahir } \\
\text { (per 1000 orang) }\end{array}$ & $\begin{array}{l}\text { Jangka hayat } \\
\text { (tahun) }\end{array}$ \\
\hline 1950 & 43.8 & 6.4 & 114.4 & 52.8 \\
1960 & 43.4 & 6.4 & 71.9 & 59.6 \\
1970 & 35.0 & 5.1 & 43.1 & 64.3 \\
1980 & 31.3 & 4.1 & 26.1 & 67.9 \\
1990 & 28.2 & 3.6 & 14.3 & 70.7 \\
2000 & 22.6 & 2.9 & 9.0 & 72.5 \\
2010 & 17.4 & 2.2 & 6.8 & 74.4 \\
2020 & 16.5 & 2.0 & 5.6 & 76.2 \\
2021 & 16.3 & 1.9 & 5.5 & 76.4 \\
\hline
\end{tabular}

Sumber: Unjuran Pertubuhan Bangsa-bangsa Bersatu (United Nation) (2021)

\section{Metod Kajian}

Kajian ini bertujuan untuk (1) mengenai aspek yang mempengaruhi penuaan aktif; (2) perancangan polisi dan dasar kerajaan dalam mencapai penuaan aktif untuk mencapai kesejahteraan hidup dan; (3) cabaran dalam pencapaian penuaan aktif. Penyelidik menggunakan teknik analisis sorotan literatur yang diperkenalkan oleh Tricco et al. (2018) iaitu skema PRISMA Extension for Scoping Reviews (PRISMAScR): Checklist and Explanation sebagai medium pendekatan kajian ini. Menurut Sierra-Correa dan Cantera Kintz (2015), penggunaan PRISMA memungkinkan untuk menentukan persoalan kajian yang jelas, meneliti secara luas dalam pangkalan data saintifik dalam masa yang ditentukan dan mengenal pasti kriteria pengecualian (exclusion) dan kemasukan (inclusion).

\subsection{Prosedur dan Tatacara dalam pengumpulan data}

Analisis kandungan data empirikal dalam sumber sekunder adalah teknik pengumpulan maklumat bagi mempersembahkan hasil tinjauan kajian-kajian lepas yang dijalankan 
oleh sarjana-sarjana dalam bidang yang berkaitan. Tema kajian ini adalah mengenai konsep Penuaan Aktif dijadikan sebagai fokus pencarian manakala sub-sub tema yang berkaitan adalah i) faktor dalam penentuan penuaan aktif; ii) strategi perancang polisi dan kerajaan dalam memperkasakan penuaan aktif dalam penduduk warga emas dan iii) cabaran dalam pencapaian penuaan aktif dalam kalangan warga emas. Tahun pencarian dihadkan dari tahun 2002 dimana konsep penuaan aktif diperkenalkan pada tahun 2002 namun hanya sumber empirikal yang terkini iaitu dari tahun 2010 hingga 2021 digunakan untuk dipetik dalam penulisan kertas kerja ini. Teknik analyst content yang diutara oleh Tricco et al. (2018) dalam penulisan hasil dapatan daripada pengekstrakan sorotan literatur kajian-kajian lepas secara bersusun atur dan sistematik dapat meningkatkan mutu penulisan dari segi kebolehpercayaan, transparensi dan kredibiliti.

\subsection{Prosedur pemilihan karya literatur}

Terdapat tiga tahap dalam pemilihan karya literatur dalam penganalisisan sorotan literatur sebagai hasil penemuan iaitu, pengenalpastian, penapisan dan pemilihan kelayakan. Rajah 2 menerangkan prosedur pemilihan karya literatur yang diaplikasikan dalam kajian ini berpandukan pendekatan yang diperkenalkan oleh Micah et al. (2015).

\subsubsection{Pengenal pastian}

Proses mengkaji semula karya literatur sarjana lepas dimulakan pada bulan September 2021 untuk mencari idea yang ingin disimpulkan dalam kertas kerja ini. Peringkat yang pertama adalah mengenal pasti dan menentukan kata kunci yang digunakan untuk dijadikan fokus pencarian agar tidak berlaku kebingungan dalam proses pencarian di enjin pencarian. Kata kunci yang digunakan adalah berkaitan dengan penuaan aktif daripada pangkalan data atas talian seperti Scopus, Science Direct, Google Scholar dan Academia seperti yang diringkaskan dalam Jadual 3.

Jadual 3: Kata kunci dan strategi pencarian maklumat

\begin{tabular}{ll}
\hline Pangkalan data & Kata kunci yang digunakan \\
\hline Dimensi & "Penuaan", "fenomena penuaan", "Penuaan aktif", "warga emas" \& \\
& "Malaysia" \\
\hline $\begin{array}{l}\text { Scopus, Science Direct, } \\
\text { Google Scholar \& }\end{array}$ & "Active aging", "ageing", "elderly", "Penuaan aktif", "kehidupan \\
Academia. & aktif selepas persaraan" \& "Malaysia" \\
\hline
\end{tabular}

Sumber: Diubahsuai daripada Micah et al. (2015)

\subsubsection{Penapisan}

Tujuan penyaringan peringkat pertama adalah untuk menghapus artikel pendua. Dalam kes ini, jumlahnya daripada lima artikel dikecualikan semasa peringkat pertama, sementara 285 artikel disaring berdasarkan beberapa kriteria kemasukan (inclusion) dan pengecualian (exclusion) ditentukan oleh penyelidik pada tahap kedua, seperti yang ditunjukkan dalam Jadual 4. Kriteria pertama adalah jenis literatur di mana para penyelidik memutuskan untuk hanya memfokuskan pada jurnal (artikel penyelidikan) kerana ia merupakan sebagai sumber utama yang menawarkan data empirikal. 
Jadual 4 : Kriteria Inclusion dan Exclusion

\begin{tabular}{ll}
\hline Kategori & Kriteria \\
\hline Kemasukan & Tajuk jurnal yang mengandungi "Penuaan aktif” sahaja. \\
(inclusion) & Abstrak Jurnal yang menerangkan tentang konsep “Penuaan aktif”. \\
& Kajian yang berperingkat nasional atau antarabangsa. \\
& Jurnal yang berjenis review dan research akan dipilih. \\
& Tempoh penerbitan jurnal adalah antara tahun 2011 hingga 2021 sahaja. \\
& Jurnal yang boleh diakses sahaja dapat digunakan. \\
Pengecualian & Tajuk artikel atau jurnal yang tidak menyatakan "penuaan aktif”. \\
(exclusion) & Kajian yang tidak berkaitan dengan warga emas. \\
& Jurnal yang bukan bidang kemanusiaan dan sains sosial. \\
& Jurnal yang diterbitkan sebelum tahun 2011. \\
& Jurnal yang berbahasa selain Bahasa Malaysia dan Bahasa Inggeris tidak \\
& akan dipilih. \\
\hline
\end{tabular}

\subsubsection{Pemilihan kelayakan}

Selepas penapisan daripada 285 buah jurnal pada peringkat pertama yang dimuat turun daripada pangkalan data seperti Scopus, Google Scholar, Science direct dan juga Academia, artikel yang tidak berkaitan dengan skop kajian telah ditapis (bukan dalam bidang kemanusiaan dan sains sosial) tinggal 56 buah jurnal dan akan ditapis lagi untuk peringkat kedua. Pada peringkat kedua, jurnal yang tidak menepati fokus pencarian (tajuk dan abstrak) akan disaringkan dan hanya tinggal 20 buah jurnal akan diteliti secara menyeluruh. Akhir sekali, hanya 12 buah artikel yang dapat diakses akan digunakan untuk dikaji semula dalam kertas penyelidikan ini, seperti yang diringkas dalam Rajah 2.

Rajah 2: Carta aliran dalam analisis penapisan menggunakan Preferred Reporting Items for Systematic Reviews

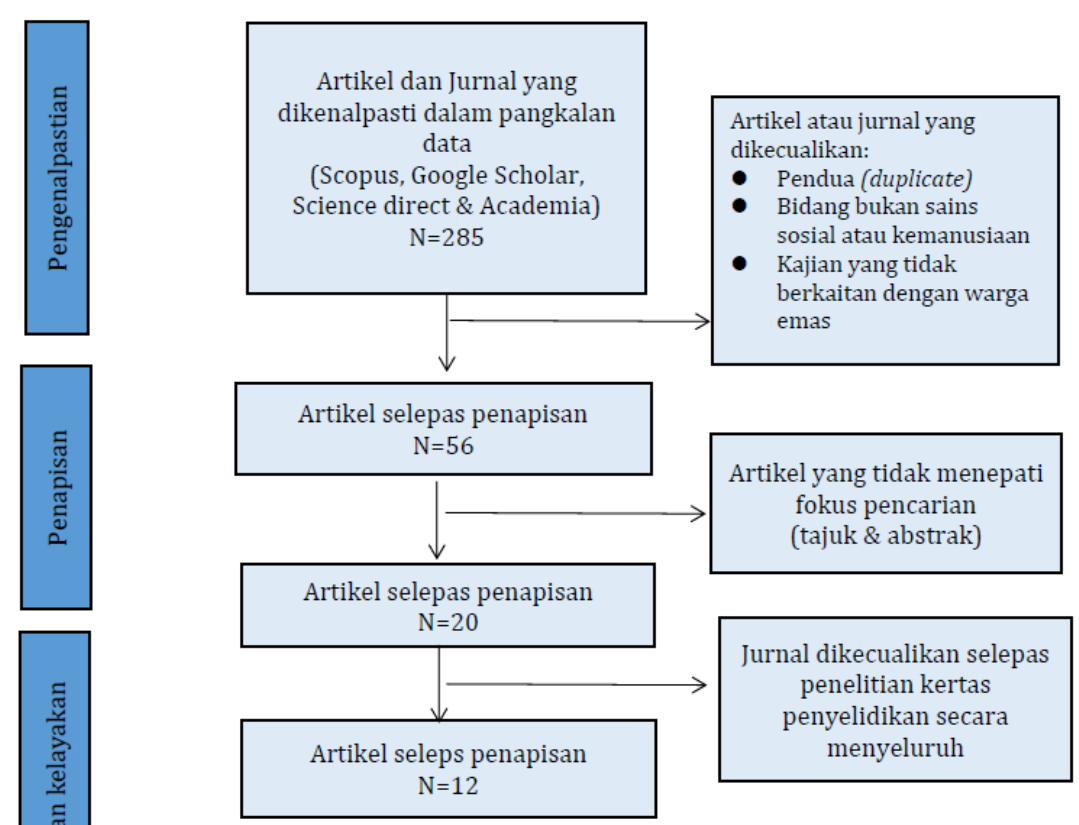

Sumber: Diadaptasi daripada Micah et al. (2018) 


\section{Hasil kajian}

Jadual 5 menunjukkan hasil dapatan mengenai definisi dan takrifan tentang konsep penuaan aktif. Hasil kajian mendapatkan faktor penentuan yang diperkenalkan oleh WHO (2000) merupakan akar bagi pemberian makna kepada penuaan aktif daripada pelbagai negara.

\section{Jadual 5: Analisis Takrifan penuaan aktif}

\begin{tabular}{|c|c|c|c|c|}
\hline Bil & $\begin{array}{l}\text { Nama pengarang } \\
\text { /tahun } \\
\text { penerbitan }\end{array}$ & Tajuk & $\begin{array}{l}\text { Metodologi yang } \\
\text { digunakan }\end{array}$ & Butiran \\
\hline 1 & $\begin{array}{l}\text { World Health } \\
\text { Organization } \\
(2002)\end{array}$ & $\begin{array}{l}\text { Towards a } \\
\text { common } \\
\text { language for } \\
\text { functioning, } \\
\text { disability, and } \\
\text { health }\end{array}$ & $\begin{array}{l}\text { Memperkenalkan } 6 \\
\text { penentu yang boleh } \\
\text { menyumbang } \\
\text { kepada penuaan } \\
\text { aktif. } \\
\text { Mengeluarkan } \\
\text { Kerangka Polisi } \\
\text { Penuaan Akif dan } \\
\text { dibentangkan di } \\
\text { Madrid. }\end{array}$ & $\begin{array}{l}\text { Penuaan aktif berlaku dalam } \\
\text { kedua-dua konteks individu } \\
\text { dan juga kumpulan komuniti. } \\
\text { Penentu adalah sosial, ekonomi, } \\
\text { perkhidmatan kesihatan dan } \\
\text { sosial, tingkahlaku, peribadi } \\
\text { dan persekitaran fizikal. }\end{array}$ \\
\hline 2 & $\begin{array}{l}\text { Portegijs et al. } \\
(2022)\end{array}$ & $\begin{array}{l}\text { Impact of } \\
\text { mobility } \\
\text { restrictions on } \\
\text { active aging; } \\
\text { cross-sectional } \\
\text { associations and } \\
\text { longitudinal } \\
\text { changes parallel } \\
\text { to COVID-19 } \\
\text { restrictions }\end{array}$ & $\begin{array}{l}\text { Data kohort AGNES } \\
\text { dikumpul pada } \\
\text { 2017-2018. Ini } \\
\text { adalah analisis } \\
\text { keratan rentas dan } \\
\text { prospektif bagi data } \\
\text { kohort. }\end{array}$ & $\begin{array}{l}\text { Penuaan aktif merujuk kepada } \\
\text { pendekatan hidup yang aktif } \\
\text { selaras dengan matlamat, } \\
\text { keupayaan dan peluang } \\
\text { seseorang. Kajian ini cenderung } \\
\text { menerangkan penentu peribadi } \\
\text { seseorang untuk mencapai } \\
\text { penuaan aktif. Penuaan aktif } \\
\text { meliputi kehendak, kebolehan, } \\
\text { peluang dan tahap melakukan } \\
\text { aktiviti. Penuaan aktif juga } \\
\text { merujuk kepada ketahanan dan } \\
\text { sokongan luaran sebagai } \\
\text { pengubah hasil hilang upaya. }\end{array}$ \\
\hline 3 & $\begin{array}{l}\text { Kementerian } \\
\text { Pembangunan } \\
\text { Wanita, Keluarga } \\
\text { dan Masyarakat } \\
.(2011) .\end{array}$ & $\begin{array}{l}\text { Dasar Warga } \\
\text { Emas Negara }\end{array}$ & $\begin{array}{l}\text { Memperkenalkan } \\
\text { dasar. }\end{array}$ & $\begin{array}{l}\text { Penuaan aktif didefinisikan } \\
\text { sebagai proses } \\
\text { mengoptimumkan peluang dan } \\
\text { penglibatan warga emas dalam } \\
\text { keluarga dan masyarakat ke } \\
\text { arah mendayaupayakan warga } \\
\text { emas untuk meningkatkan } \\
\text { kesejahteraan hidup. }\end{array}$ \\
\hline 4 & $\begin{array}{l}\text { Rantanen et al. } \\
\text { (2019) }\end{array}$ & $\begin{array}{l}\text { Developing an } \\
\text { Assessment } \\
\text { Method of Active } \\
\text { Aging: University } \\
\text { of Jyvaskyla } \\
\text { Active Aging } \\
\text { Scale }\end{array}$ & $\begin{array}{l}\text { Membangunkan } \\
\text { Skala Penuaan Aktif } \\
\text { Universiti Jyvaskyla } \\
\text { iaitu } 17 \text { item dengan } \\
\text { empat aspek: } \\
\text { (matlamat, } \\
\text { keupayaan, peluang } \\
\text { dan aktiviti) }\end{array}$ & $\begin{array}{l}\text { Penuaan aktif seperti yang } \\
\text { ditakrifkan dari perspektif } \\
\text { warga emas memerlukan } \\
\text { aktiviti yang sejajar dengan } \\
\text { matlamat, kapasiti dan peluang } \\
\text { yang ada untuk elemen } \\
\text { kesejahteraan melalui aktiviti } \\
\text { yang berkaitan dengan } \\
\text { matlamat, kapasiti fungsi dan } \\
\text { peluang seseorang. Penuaan } \\
\text { aktif adalah untuk mengekalkan } \\
\text { atau menggalakkan } \\
\text { kesejahteraan. }\end{array}$ \\
\hline 5 & $\begin{array}{l}\text { Stenner et al. } \\
\text { (2011) }\end{array}$ & $\begin{array}{l}\text { Older people and } \\
\text { active ageing: } \\
\text { Subjective aspects }\end{array}$ & $\begin{array}{l}\text { Kualitatif temu bual } \\
\text { dengan } 47 \text { orang } \\
\text { informan. Analisis }\end{array}$ & $\begin{array}{l}\text { Penuaan aktif difahami } \\
\text { berkaitan dengan faktor fizikal, } \\
\text { kognitif, psikologi dan sosial. }\end{array}$ \\
\hline
\end{tabular}


of ageing actively tematik digunakan bagi analisis data.

6 Hijas-Gómez et al. (2020)

$7 \quad$ Mendoza-Núñez et al. (2009)

The WHO active
ageing pillars and
its association
with survival:
Findings from a
population-based
study in Spain

Pendekatan

campuran. Data

daripada sampel

801 orang dewasa

yang tinggal dalam

komuniti. Kaitan

antara komponen

(pillars) akan

dianalisis dengan multiple regression. Kualitatif digunakan untuk mengetahui aktiviti yang dijalankan

Implementation of an active aging model in Mexico for prevention and control of chronic diseases in the elderly
Kuantitatif dengan jumlah sampel 400 warga tua di bandar dan penduduk luar bandar yang tinggal di Negeri Hidalgo, Mexico selama lima tahun.
Kajian literatur yang komprehensif telah dijalankan untuk mengenal pasti keperluan warga emas dalam menggunakan kawasan lapang awam. Kaedah kualitatif iaitu kumpulan sasaran dijalankan dan data dianalisis guna
Tetapi ini wujud bersama

dalam gabungan yang kompleks. Pengertian aktiviti dalam penuaan aktif difahami berkaitan dengan perbezaan aktif/pasif yang menekankan peningkatan atau pengurangan kuasa konkrit aktiviti. Penuaan aktif bergantung kepada peletakan persekitaran seperti kejiranan kerana mampu menentukan minat perjalanan warga emas. Kajian ini lebih menumpukan kepada peletakan lokasi sukan yang selain rumah untuk melihat adakah peletakan sesuatu destinasi mempunyai pertimbangan fungsi kognitif warga emas. Dapatan menunjukkan peletakan kemudahan dan infrastruktur untuk tujuan rekreasi dan perniagaan di persekitaran tempat kediaman menyokong fungsi kognitif warga emas. Ini akan menyebabkan warga emas lebih aktif menuju ke persekitaran sekitarnya. Indikator tahap kesihatan merupakan komponen dalam menentukan penuaan secara aktif. Warga emas lebih terdedah kepada pelbagai penyakit kronik. Model rangka kerja ini akan merangkumi 6 penentu yang dicadangkan oleh WHO dimana: (1) perkhidmatan kesihatan dan sosial; (2) tingkah laku; (3) peribadi; (4) persekitaran fizikal; (5) sosial; (6) ekonomi yang tertanam dalam konteks budaya dan jantina dengan cadangan dasar kesihatan untuk warga emas, untuk dilaksanakan melalui rancangan kesihatan nasional di seluruh dunia.

Kajian ini menekankan bahawa perancangan kawasan lapang awam di kawasan bandar harus memenuhi keperluan sosial khas warga emas. Ditegaskan bahawa salah satu keperluan sosial utama mereka adalah mengekalkan interaksi yang berterusan antara satu sama lain untuk mengelakkan perasaan kesunyian. 
perisian Nvivo10.

$9 \quad$ Ann Bowling (2007).

10 Annear et al. (2012).

11 Robbins et al. (2018)

12 Carstairs \& Keon (2007)
Enhancing later life: How older people perceive active ageing?

Environmental influences on healthy and active ageing: a systematic review.

\section{E-health for} active ageing; $A$ systematic review

\section{Embracing the challenge of aging Embracing the challenge of aging.}

Interviews bersemuka dengan 337 orang warga emas di tinggal di Britain.

Penilaian sistematik 83 kajian kuantitatif dan kualitatif. Prosedur semakan jenis Cochrane telah diikuti, yang menggabungkan carian pangkalan data berstruktur, kriteria kemasukan dan pengecualian, penilaian kualiti kajian yang disertakan, dan semakan peer reviews.

Kajian sistematik telah dijalankan mengikut piawaian PRISMA.Pangkalan data adalah Cochrane, EMBASE \& CINAHL, dengan pengekstrakan bebas untuk membentuk borang soal selidik semi berstruktur. Kajian sorotan literatur dalam perancang dasar dan polisi penuaan aktif.
Kajian ini melihat persepsi warga emas terhadap konsep penuaan aktif. Pengekalan kesihatan dan fungsi fizikal, aktiviti riadah dan sosial, aktiviti kaunseling mental adalah aspek yang boleh diukur adakah warga emas tersebut aktif. Penglibatan sosial dilihat penting dalam konteks ini. Pengaruh individu, pengaruh sekitar, kemudahan dan infrastruktur, sosioekonomi, tingkah laku dan rangkaian sosial merupakan penentu dalam konsep penuaan aktif.
Penggunaan digital dalam kesihatan seperti teleperubatan dan e-kesihatan adalah trend strategi perubatan bagi warga emas. Strategi intervensi dikesan sebagai strategi yang paling berkesan kerana kos yang lebih mampu dimiliki.

Penuaan aktif adalah penyertaan diri dalam menunjukkan kepada kesan berfaedah contohnya penyertaan sukan dan sosiobudaya ke atas mengekalkan mental dan kesihatan fizikal dan kualiti hidup.

\subsection{Tonggak penuaan aktif}

Rajah 3 menunjukkan penentu bagi penuaan aktif iaitu kesihatan, penyertaan dan keselamatan. Kesihatan yang dinyatakan di sini adalah pencegahan dan kawalan penyakit kronik, serta menjaga, memanjangkan, dan memulihkan fungsi fizikal, mental, dan sosial mengikut usia warga emas dan konteks sosiobudaya tertentu harus dianggap sebagai elemen asas berkaitan dengan kesihatan. Penyertaan adalah peluang harus 
disediakan yang memungkinkan warga emas untuk memiliki penyertaan sosial yang produktif dalam kegiatan yang bergaji dan tidak berbayar dalam program yang berkaitan dengan pengembangan sosial, pekerjaan, pendidikan, kesihatan, pengembangan budaya dan kerohanian dan lain-lain. Polisi harus dibuat yang menjamin akses tetap ke kesihatan, makanan, perumahan dan kesejahteraan bagi orang dewasa yang berfungsi dan juga bagi mereka yang memerlukan perawatan instrumental bagi menjamin keselamatan warga emas.

Rajah 3: Faktor penentu dalam konsep penuaan aktif

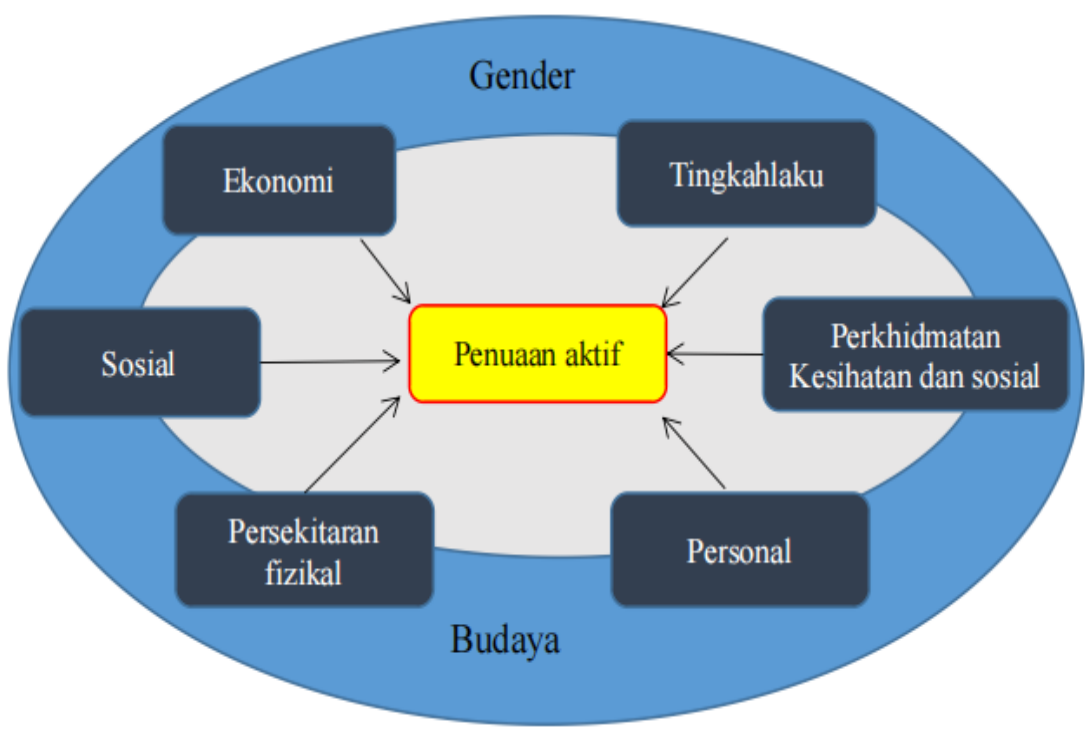

Sumber: Pertubuhan Kesihatan Sedunia (WHO) (2011)

\subsection{Faktor Penentuan dalam Penuaan Aktif}

Rajah 3 menunjukkan penentu bagi penuaan aktif dalam kalangan warga emas yang telah disimpulkan oleh WHO. Elemen budaya dan gender adalah faktor penentu silang dalam rangka konseptual untuk memahami konsep penuaan aktif. Nilai dan tradisi budaya menentukan sebahagian besarnya bagaimana masyarakat tertentu memandang warga emas dan proses penuaan. WHO menegaskan bahawa kualiti hidup adalah persepsi individu tentang kedudukan dalam kehidupan dari segi konteks budaya dan sistem nilai di mana seseorang itu hidup dan berkait rapat dengan matlamat, harapan, piawaian dan kebimbangan seseorang dalam kehidupan mereka (WHO, 1998). Pembuat dasar di sesebuah negara memperlihatkan kualiti hidup sebagai konsep tersusun bagi pertimbangan dalam membentuk polisi dan tindakan bagi meningkatkan taraf kehidupan manusia (Walker \& Maltby, 2012). Menurut Siti Nadira et al. (2015), kesejahteraan hidup dan kualiti hidup sememangnya berkait rapat dan impak besar kepada pembangunan negara. Apabila masyarakat lebih cenderung untuk mengaitkan gejala ketidakselesaan dengan proses penuaan, mereka cenderung untuk memberikan pencegahan, pengesanan awal dan perkhidmatan rawatan yang sesuai. Budaya adalah faktor utama warga emas dalam membuat keputusan sama ada tinggal bersama atau tidak dengan generasi muda sebagai alternatif terus kehidupan selepas meninggalkan persekitaran pekerjaan. Sebagai contoh, di negara Asia, norma budaya adalah berstruktur tradisi keluarga besar dan lebih cenderung hidup bersama dengan varisi generasi isi rumah. 
Faktor budaya akan mempengaruhi tingkah laku dalam aspek kesihatan kerana terdapat kepelbagaian budaya dan kerumitan yang sangat besar di dalam sesebuah negara dan juga antara negara dan kawasan di dunia. Contohnya, pelbagai etnik membawa pelbagai nilai, sikap dan tradisi kepada budaya arus perdana di dalam sebuah negara. Dasar dan program perlu menghormati budaya dan tradisi semasa sambil membongkar stereotaip yang ketinggalan zaman dan maklumat yang salah. Lebih-lebih lagi, terdapat nilai sejagat kritikal yang melampaui budaya, seperti etika dan hak asasi manusia. Dalam banyak kelompok masyarakat, perempuan dan wanita mempunyai status yang lebih rendah dan kekurangan akses dalam pendudukan, pekerjaan, keperluan dan juga perkhidmatan sosial. Di sesetengah negara, peranan tradisional wanita sebagai pengasuh keluarga juga boleh menyumbang kepada peningkatan kemiskinan dan kesihatan yang buruk pada usia yang lebih tua. Sebilangan wanita terpaksa melepaskan pekerjaan yang dibayar untuk melaksanakan tanggungjawab pengasuhan mereka. Tambahan lagi, kepelbagaian tanggungjawab wanita yang menyumbang kepada keluarga seperti menjaga ibu bapa yang lebih tua, pasangan yang sakit serta anak cucu tidak akan dapat sebarang balasan. Hal ini sedemikian kerana golongan lelaki lebih cenderung mengalami kecederaan parah atau kematian kerana melibatkan diri dalam sektor pekerjaan yang berisiko tinggi. Menurut Luciana (2016), di Convention on the Elimination of All Forms of Discrimination Against Women (CEDAW) telah menyuarakan persoalan dalam mengupayakan kesetaraan hak-hak sosial dan pemberdayaan perempuan dari diskriminasi dan pelanggaran hak asasi perempuan di India terbuktilah bahawa gender merupakan salah satu unsur yang perlu dipertimbangkan dalam pencapaian penuaan aktif.

\subsubsection{Perkhidmatan kesihatan dan sosial}

Dalam usaha menggalakkan penuaan aktif, sistem kesihatan perlu memberi perhatian kepada kempen promosi terhadap kesedaran dalam penjagaan kesihatan, pencegahan penyakit kronik dan pengaksesan yang saksama kepada kualiti penjagaan kesihatan dan rawatan dalam jangka masa panjang. Promosi kesihatan adalah proses pengaktifan masyarakat untuk mengawal dan merawat kesihatan mereka. Pencegahan penyakit merangkumi langkah pencegahan dan juga pengurusan masalah kesihatan yang biasa berlaku apabila usia berlanjutan. Walaupun terdapat usaha terbaik dalam promosi penjagaan kesihatan dan pencegahan penyakit, semakin meningkat jumlah penduduk risiko menghidap penyakit ketika mereka meningkat usia.

Oleh itu, akses ke perkhidmatan rawatan sangat diperlukan. Sebagai sebahagian besar warga emas di mana-mana negara tertentu tinggal dalam komuniti, kebanyakan perkhidmatan rawatan ditawarkan oleh sektor penjagaan kesihatan asas. Selain itu, seiring bertambahnya usia, permintaan terhadap ubat-ubatan untuk merawat penyakit kronik dan mengurangkan kesakitan akan terus meningkat bagi meningkatkan kualiti hidup. Ini memerlukan pengawalan ketat terhadap pembekalan ubat-ubatan agar selamat digunakan dan penciptaan perubatan yang baru bagi memenuhi keperluan pesakitnya. Antara pihak berkepentingan dalam pengurusan keselamatan ubat-ubatan adalah kerajaan, profesional kesihatan, industri pembuatan ubat, penyembuh tradisional, institusi dan organisasi yang mewakili warga emas. Penjagaan jangka panjang ditakrifkan oleh WHO (2000), adalah sistem aktiviti yang dijalankan secara tidak formal seperti (keluarga, rakan dan atau jiran) dan profesional (perkhidmatan kesihatan dan sosial) untuk memastikan bahawa seseorang yang tidak mempunyai kebolehan menjaga kesihatan diri dapat mengekalkan kualiti hidup yang tertinggi. 
Penjagaan jangka panjang merangkumi kedua-dua sistem sokongan tidak formal dan formal yang merangkumi pelbagai perkhidmatan masyarakat misalnya, kesihatan awam, penjagaan asas, penjagaan di rumah, perkhidmatan pemulihan dan penjagaan melegakan ketidakselesaan serta penjagaan institusi di rumah jagaan dan rumah tumpangan. Berdasarkan statistik daripada Kementerian Pembangunan Wanita, Keluarga dan Masyarakat (2017), Jabatan Kebajikan Masyarakat telah menubuhkan Rumah Seri Kenangan dan Rumah Ehsan untuk memberi penjagaan dan perlindungan kepada warga emas yang daif. Setakat ini, terdapat 11 buah Rumah Seri Kenangan termasuk di Sarawak dan 3 buah Rumah Warga Tua di Sabah memberi penjagaan dan perlindungan kepada seramai 2,553 orang penghuni. Selain itu, terdapat 2 buah Rumah Ehsan yang memberi penempatan seramai 227 orang penghuni di mana seramai 215 orang penghuni daripadanya adalah warga emas. Berdasarkan data daripada laman sesawang Kementerian Pembangunan Wanita, Keluarga dan Masyarakat (2017), terdapat 385 buah pusat penjagaan warga emas telah berdaftar di Malaysia bagi memberi penjagaan kepada warga emas di seluruh Malaysia.

\subsubsection{Tingkah laku}

Penerapan gaya hidup sihat dan mengambil bahagian secara aktif dalam satu penjagaan diri adalah penting di semua peringkat perjalanan hidup. Pengamalan gaya hidup sihat dengan melakukan aktiviti fizikal, pengambilan makanan yang berkhasiat, tidak merokok atau mengambil alkohol pada usia warga emas boleh mencegah penyakit dan memanjangkan umur dan jangka hayat. Residen Bahagian Sarikei Mohamad Junaidi Mohidin berkata warga emas digalakkan melakukan senaman ringan mengikut kemampuan fizikal tubuh (Utusan Borneo Online, 2018). Beliau juga menyatakan bahawa negara kita kini menuju status negara tua pada 2030 dengan 15 peratus daripada penduduk berusia 60 tahun dan ke atas. Dalam menangani senario demografi ini semua pihak perlu berganding bahu mewujudkan persekitaran sosial, ekonomi dan kesihatan sesuai bagi menjamin kesejahteraan hidup warga emas selaras dengan Dasar Warga Emas Negara yang menyasarkan warga emas berdikari, aktif, proaktif dan produktif.

\subsubsection{Peribadi}

Faktor keperibadian dimaksudkan oleh WHO (2000) adalah berkaitan dengan ciri-ciri biologi dan juga genetik serta unsur psikologi seseorang dalam pencapaian penuaan aktif. Biologi dan genetik sangat mempengaruhi bagaimana seseorang itu telah mencecah usia warga emas. Penuaan adalah satu set proses biologi yang ditentukan secara genetik. Penuaan boleh didefinisikan sebagai progresif, umumnya gangguan fungsi yang mengakibatkan kehilangan tindak balas adaptif terhadap tekanan dan peningkatan risiko penyakit yang berkaitan dengan berlanjutan usia (Kirkwood,1996). Dengan kata lain, sebab utama mengapa warga emas jatuh sakit lebih kerap daripada golongan muda adalah kerana warga emas lebih terdedah kepada luaran, faktor tingkah laku dan persekitaran yang menyebabkan mereka mudah menghidap penyakit berbanding dengan golongan muda dalam tempoh masa panjang (Gray, 1996). Di samping itu, faktor psikologi termasuk kecerdasan dan keupayaan kognitif (contohnya, kemampuan untuk menyelesaikan masalah dan menyesuaikan diri dengan perubahan dan kehilangan) adalah indikator penuaan aktif dan umur panjang (Smits et al., 1999). Semasa mencapai usia keuzuran, keupayaan kognitif seperti kelajuan bergerak dan ingatan secara semula jadinya akan menurun seiring dengan pertambahan usia. Isu kesihatan yang dialami oleh warga tua akibat daripada keuzuran telah menyebabkan 
mobiliti mereka terbatas. Menurut Siti Zaila dan Khadijah (2016), dalam kajiannya mengatakan bahawa peningkatan usia yang dialami oleh warga emas telah menyebabkan berlakunya perubahan atau penurunan fizikal dan psikologikal dalam kalangan warga emas itu sendiri. Kaniz dan Sara (2019), menyatakan bahawa majoriti warga tua di Melbourne berhenti memandu kerana keadaan kesihatan yang lemah. Atas sebab kesihatan mereka mengundurkan diri daripada menggunakan perkhidmatan pengangkutan awam sebagai pilihan. Ho (2016), lebih menumpu kepada warga emas yang mengalami hilang upaya adalah sangat berisiko untuk memandu. Misalnya, mempunyai masalah dari segi penurunan fungsi penglihatan dan pendengaran berkaitan dengan umur mereka serta pergerakan yang terlampau perlahan akan menyebabkan tindak balas mereka menjadi perlahan dan ia akan membahayakan pemandu lain di jalan raya di samping membahayakan diri mereka sendiri. Terdapat banyak kajian telah menunjukkan pemandu warga emas mengalami masalah tindakan lambat dan kepelbagaian halangan penglihatan (USDOT, 1997; Fozard, 1990; Goggin et al., 1989).

\subsubsection{Persekitaran fizikal}

Persekitaran fizikal yang mesra spesifikasi orang awam boleh menyebabkan perbezaan antara pergantungan dan kebergantungan bagi semua individu tetapi sangat penting bagi mereka yang semakin tua. Sebagai contoh, warga emas yang tinggal di persekitaran yang tidak selamat atau kawasan dengan pelbagai halangan fizikal kurang mendapat keluar dan oleh itu lebih terdedah kepada pengasingan, kemurungan, kecergasan berkurang dan meningkat masalah mobiliti. Perhatian khusus harus diberikan kepada warga emas yang tinggal di luar bandar (sekitar 60 peratus di seluruh dunia) di mana corak penyakit berbeza kerana keadaan persekitaran dan kekurangan perkhidmatan sokongan yang tersedia. Pembandaran dan penghijrahan warga emas untuk pencarian pekerjaan di kawasan bandar dengan meninggalkan warga emas di kawasan luar bandar akan mengakibatkan warga emas terpencil dengan sistem sokongan dari segi kemudahan dan infrastruktur dan tambahan lagi pengaksesan terhadap perkhidmatan kesihatan dan sosial yang terhad.

Perkhidmatan pengangkutan awam yang mudah diakses dan berpatutan diperlukan di luar bandar dan di kawasan bandar supaya masyarakat dari semua peringkat umur dapat sepenuhnya mengambil bahagian dalam kehidupan keluarga dan masyarakat. Ini sangat penting bagi warga emas yang mempunyai masalah mobiliti agar dapat kekal aktif samada dalam fisiologi atau psikologi diri seseorang. Warga emas menghadapi pelbagai halangan dalam mobiliti yang telah menjejaskan kualiti hidup mereka kerana menurut de Jong dan Brouwer (2012) salah satu aspek utama meningkatkan kualiti hidup warga adalah mobiliti yang merangkumi dimensi yang berbeza iaitu perumahan, pengangkutan, aktiviti pekerjaan dan interaksi sosial. Pembekalan keperluan asas seperti perumahan yang selamat, air dan udara serta keselamatan makanan akan mempengaruhi kualiti hidup warga emas. Penempatan rumah warga emas perlu ditempatkan berdekatan dengan keperluan harian seperti hospitaliti dan rawatan, tempat rekreasi dan riadah. Air bersih, udara bersih dan akses kepada makanan yang selamat sangat penting bagi kumpulan populasi yang paling rentan, iaitu kanak-kanak dan warga emas khususnya juga bagi mereka yang mempunyai penyakit kronik dan sistem imun yang terganggu. 


\subsubsection{Sosial}

Sokongan sosial, peluang untuk pendidikan dan pembelajaran seumur hidup, kedamaian dan perlindungan dari keganasan dan penderaan adalah faktor utama dalam persekitaran sosial yang meningkatkan kesihatan, penyertaan dan keselamatan seiring bertambahnya usia. Kesunyian sepi, pengasingan sosial, buta huruf dan kekurangan pendidikan, penyalahgunaan dan pendedahan dalam situasi konflik sangat meningkatkan risiko orang tua untuk kecacatan dan kematian awal. Sokongan sosial yang tidak mencukupi tidak hanya dikaitkan dengan peningkatan kematian, morbiditi dan tekanan psikologi tetapi juga membawa kepada penurunan dalam keseluruhan kesihatan dan kesejahteraan umum. Warga emas lebih cenderung kehilangan keluarga ahli dan rakan dan menjadi lebih rentan terhadap kesepian, pengasingan sosial dan ketersediaan dalam kumpulan sosial yang lebih kecil.

Pengasingan sosial warga emas dikaitkan dengan penurunan keupayaan fizikal dan kesejahteraan mental. Hal ini sedemikian kerana mengurangkan keyakinan personal dan aksesibiliti terhadap aktiviti yang ingin dijalankan. Secara lama-kelamaan, golongan warga emas akan dipinggirkan kumpulan masyarakat yang lain (Carp, 1988). Warga emas yang lemah atau tinggal sendirian mungkin merasa sangat terdedah kepada jenayah seperti kecurian dan serangan. Satu bentuk keganasan yang biasa terhadap warga emas (terutamanya terhadap wanita) adalah "penderaan penatua" yang dilakukan oleh keluarga anggota dan penjaga institusi yang terhadap dengan mangsa. Penderaan dalam rumah tangga berlaku dalam keluarga di semua peringkat ekonomi. Ia cenderung meningkat dalam masyarakat yang mengalami pergolakan ekonomi dan kekacauan sosial daripada gejala jenayah. Tahap pendidikan dan buta huruf yang rendah dikaitkan dengan peningkatan risiko kecacatan dan kematian di kalangan warga emas ketika mereka meningkat usia dan juga dengan kadar pengangguran yang lebih tinggi. Pendidikan membantu warga emas mendapatkan peluang pembelajaran sepanjang hayat dapat membantu mereka mengembangkan kemahiran dan keyakinan yang mereka perlukan untuk menyesuaikan diri dengan kemajuan teknologi dan kekal berdikari seiring bertambahnya usia.

\subsubsection{Ekonomi}

Tiga aspek persekitaran ekonomi mempunyai kesan yang sangat ketara kepada penuaan aktif iaitu pendapatan, pekerjaan dan perlindungan sosial. Konsep penuaan aktif perlu dilaksanakan untuk mengurangkan kemiskinan pada semua peringkat usia. Masalah utama yang dihadapi oleh warga emas adalah kekangan kewangan. Hal ini sedemikian akibat daripada golongan warga tua sering kali mengalami masalah kewangan dalam membiayai perbelanjaan harian, kos perubatan, pembayaran cukai, perbelanjaan atas aktiviti sosial dan lain-lain. Akibatnya, masalah kewangan menghalang warga tua untuk mencapai kualiti hidup yang sempurna seterusnya menyebabkan kebanyakan warga tua mengalami masalah kemiskinan.

Warga emas sangat terdedah dengan masalah kemiskinan yang dihadapi dan keadaan menjadi lebih daif jika mereka dihidap sesuatu penyakit kronik. Ramai warga emas terutamanya warga emas wanita yang hidup bersendirian dan menetap di kawasan persekitaran luar bandar dan juga pinggir bandar memiliki pendapatan yang mencukupi untuk menampung perbelanjaan sara hidupnya. Ini memberi impak serius kepada mereka untuk akses kepada makanan berkhasiat, tempat tinggal yang selamat dan penjagaan kesihatan yang rapi. Kajian yang dijalankan oleh Guralnick dan Kaplan (1989) 
mendapati bahawa warga emas yang berpendapatan rendah lebih mudah terdedah dengan isu di atas berbanding dengan mereka yang mempunyai pendapatan yang lebih tinggi. Menurut Bongaarts dan Zimmer (2002), pada zaman dahulu, semua negara di dunia, keluarga warga emas akan menyediakan majoriti sokongan untuk warga emas yang memerlukan pertolongan kerana berhidupan dengan kepelbagaian generasi dalam satu keluarga. Namun, ketika masyarakat moden berkembang dan tradisi generasi hidup bersama mula merosot, kerajaan negara diseru untuk mengembangkan mekanisme yang menyediakan perlindungan sosial untuk warga emas yang tidak dapat mencari nafkah bersendirian dan merupakan tanggungan beban yang berat bagi keluarga.

Di negara membangun, warga emas lebih bergantung kepada bantuan kewangan daripada sokongan keluarga, pekerjaan tidak formal dan simpanan peribadi (OECD, 2017). Walau bagaimanapun, di negara seperti Afrika Selatan dan Namibia, warga emas menerima pencen usia tua kebangsaan dan ini merupakan sumber pendapatan bagi majoriti keluarga miskin. Hasil perolehan daripada pencen usia tua kebangsaan ini biasanya digunakan dalam pembelian makanan harian bagi isirumah, kos pengangkutan bagi hantar anak ke sekolah, melabur dala teknologi pertanian secara langsungnya memastikan kelangsungan hidup bagi banyak keluarga miskin di bandar (Stewart \& Yermo, 2009). Warga emas jika diberi manfaat dalam meneruskan kerja selepasa persaraan akan memberi faedah kepada keseluruhan masyarakat hal ini sedemikian kerana pengiktirafan yang semakin meningkat bagi menyokong penyumbangan warga emas secara aktif dan produktif dalam kerja formal, kerja tidak formal dan aktiviti sukarelawan.

\subsection{Dasar dan Strategi kerajaan dalam memperkasakan Penuaan Aktif}

\subsubsection{Dasar Warga Emas Negara}

Mengikut laporan Jabatan Perangkaan Malaysia (2018), Malaysia dijangka akan mencapai status negara tua pada tahun 2030 apabila populasi penduduk yang berusia 60 tahun dan ke atas mencecah 15 peratus daripada jumlah populasi. Ini memberi erti bahawa Malaysia akan menjadi negara tua menjelang Rancangan Malaysia ke-14. Oleh itu, perancang polisi perlu mengambil langkah persediaan awal bagi membendung isu penuaan penduduk dengan penggubalan Dasar Warga Tua Negara pada tahun 1995. Usaha yang boleh dilakukan dalam menghadapi isu penuaan dalam negara, mewujudkan sistem sokongan kepada struktur keluarga agar warga emas dapat terus hidup dalam sesuatu komuniti tersebut (Jabatan Kebajikan Masyarakat, 1995). Kerajaan telah menggubal Dasar Warga Tua Negara pada tahun 1995 dan pelan ini kemudiannya telah ditambah baik menjadi Dasar Warga Emas Negara (DWEN) pada 5 Januari 2011 (Noraida et al., 2014). Pelaksanaan DWEN dan Pelan Tindakan Warga Emas Negara perlu menjadi agenda tetap dalam mesyuarat Majlis Penasihat dan Perundingan Warga Emas Negara. Seterusnya satu Jawatankuasa Teknikal Pelaksanaan DWEN yang dipengerusikan oleh Kementerian Pembangunan Wanita, Keluarga dan Masyarakat (KPWKM) ditubuhkan bagi merangka, melaksana, memantau dan menilai programprogram yang digariskan di bawah DWEN dan Pelan Tindakan Warga Emas Negara. Jawatankuasa Teknikal ini akan dibantu oleh sebanyak tujuh buah Jawatankuasa Kecil. Matlamat DWEN adalah mendayaupayakan individu, keluarga dan masyarakat dengan menyediakan perkhidmatan mesra warga emas yang cekap dan berkesan serta membangunkan persekitaran yang membolehkan dan membantu supaya warga emas hidup sejahtera. DWEN dan Pelan Tindakan Warga Emas Negara (PTWEN) merupakan komitmen kerajaan bagi mewujudkan warga emas yang berdikari, bermartabat diri dan 
dihormati dengan mengoptimumkan potensi diri melalui penuaan sihat, positif, aktif, produktif dan menyokong untuk meningkatkan kesejahteraan hidup dalam pembangunan negara (Noraida et al., 2014).

\subsubsection{Pusat Aktiviti Warga Emas}

Pusat Aktiviti Warga Emas (PAWE) ialah tempat bagi warga emas menjalankan aktiviti harian dalam komuniti. Ia merupakan satu perkhidmatan bercorak pendampingan sosial (reaching out) dan pembangunan (developmental) kepada warga emas melibatkan kerjasama strategik antara KPWKM dengan agensi kerajaan yang lain serta pertubuhan bukan kerajaan (NGO). Menurut Sarin et al. (2018), golongan warga emas di kawasan kejiranan sosioekonomi rendah terutamanya memerlukan perhatian khusus untuk mengekalkan dan mengoptimumkan kualiti hidup mereka. Dengan menyedari keperluan warga emas untuk tinggal dengan sejahtera dalam komuniti, pihak Kementerian Pembangunan Wanita, Keluarga dan Masyarakat (KPWKM) telah menggalakkan penjagaan dalam komuniti (community based care). PAWE yang ditubuhkan pada 2001 adalah salah satu penyelesaian kepada masalah-masalah yang timbul akibat peningkatan jumlah warga emas. Penubuhan PAWE adalah bagi menggalakkan penuaan yang aktif dan produktif dalam kalangan warga emas dengan melibatkan penyertaan komuniti setempat. Datuk Seri Rina Binti Mohd Harun menyatakan bahawa kerajaan menerusi Kementerian Pembangunan Wanita, Keluarga dan Masyarakat (KPWKM) melalui Pelan Strategiknya 2021 hingga 2025, memberi penekanan kepada pembangunan warga emas di negara ini (Astro Awani, 2021). Beliau juga menyatakan bahawa menerusi Belanjawan 2021, kerajaan telah menaikkan bantuan kewangan tahunan pengendalian PAWE daripada RM33,330 kepada RM50,000 bagi melaksanakan program dan aktiviti PAWE selari dengan konsep warga emas aktif dan produktif. Peruntukkan sebanyak RM 7.15 juta telah diperuntukkan untuk memudahkan pengoperasian 143 buah PAWE di seluruh negara sebagai tanda komitmen kerajaan bagi meningkatkan kualiti hidup warga emas. Beliau berkata PAWE beroperasi berteraskan konsep Organisasi Berasaskan Komuniti yang dikendalikan oleh badan bukan kerajaan dengan kerjasama strategik KPWKM.

\subsubsection{Persatuan Pembelajaran Sepanjang Hayat Warga Emas U3A KL \& Selangor}

Persatuan Pembelajaran Sepanjang Hayat Warga Emas U3A KL \& Selangor adalah sebuah Badan Sukarela Bukan Kerajaan (NGO) yang ditubuhkan pada 25 Oktober 2010 yang berdaftar di bawah Pendaftaran Persatuan dan Pertubuhan Selangor (Institusi Penyelidikan Penuaan Malaysia, 2017). Program Pembelajaran Sepanjang Hayat (PSH) untuk warga emas diperkenalkan oleh IPPM pada April 2008. Matlamat PSH adalah untuk mempromosikan penuaan aktif, sihat dan produktif menerusi kursus dan program khas yang dipilih. PSH memberi peluang kepada setiap generasi terutamanya warga emas untuk melengkapkan dan meningkatkan potensi diri dengan ilmu pengetahuan serta kemahiran untuk hidup secara aktif dan produktif dalam keluarga dan masyarakat. Fokus strategi ini adalah kepada pelaburan modal insan yang memberi tumpuan kepada persediaan awal dan tindakan pencegahan serta usaha untuk mengukuhkan hubungan kekeluargaan masyarakat bagi meningkatkan kesejahteraan warga emas masa kini dan masa hadapan (Kementerian Pembangunan Wanita, Masyarakat dan Keluarga, 2011). Semua program yang berkaitan dengan pendidikan, latihan dan pembelajaran sepanjang hayat perlu menekankan kepada penerapan nilai murni, keseimbangan ekonomi, kesihatan, sosial, persekitaran fizikal dan kerohanian. Selain itu, ruang dan peluang bagi warga emas untuk menyumbang dalam program 
pembelajaran dan pengajaran, perkongsian pengalaman dan penyampaian ilmu serta kemahiran perlu diutamakan supaya peranan dan status mereka dapat dikekalkan dalam masyarakat.

\subsubsection{Bantuan Warga Emas}

Bantuan Warga Emas merupakan bantuan kewangan yang disalurkan kepada warga emas dari Jabatan Kebajikan Malaysia. Kadaran bantuan adalah sebanyak RM 500 sebulan bagi seseorang yang memohon. Syarat permohonan adalah seperti warganegara dan bermastautin di Malaysia, warga emas berumur 60 tahun dan ke atas, pendapatan isi rumah tidak melebihi Pendapatan Garis Kemiskinan (PGK) dan Purata Miskin Isi Rumah Semasa atau PGK Purata dan tidak menetap di mana-mana institusi kendalian Jabatan Kebajikan Malaysia atau pusat jagaan harian atau berkediaman yang memberi kemudahan atau perkhidmatan secara percuma. Di samping itu, keluarga atau waris yang menjaga warga emas tidak upaya atau terlantar boleh mendapat elaun sebanyak RM300.00 sebulan sebagai satu insentif kerajaan untuk meringankan bebanan yang ditanggung sebagai penjaga warga emas. Walau bagaimanapun, penjaga hendaklah berstatus warganegara, bermastautin di Malaysia dan pendapatan isi rumah tidak melebihi RM3,000.00. Penyaluran bantuan kewangan ini kerana warga emas yang tidak mempunyai wang simpanan di hari tua tidak mampu menguruskan kehidupan mereka dengan baik apabila di usia tua, mereka tidak lagi berupaya bekerja kuat mencari nafkah. Sekiranya keluarga mereka berpendapatan rendah dan ramai tanggungan, beban penjagaan warga emas akan semakin bertambah. Bebanan kewangan akan bertambah sekiranya warga emas mengalami hilang keupayaan fizikal dan mental. Kesan penuaan dan timbulnya pelbagai penyakit kronik memerlukan penjagaan berpanjangan serta kos perubatan yang tinggi. Selain daripada itu, penyakit kardiovaskular, masalah paru-paru, jangkitan kuman, kanser dan masalah usus merupakan lima penyebab utama kematian warga emas di hospital-hospital kerajaan. Apabila keluarga menghadapi bebanan kewangan, mereka tidak mampu menyediakan tempat tinggal yang selesa, membayar bil rawatan yang tinggi, kos pengangkutan untuk rawatan ulangan dan membeli makanan tambahan untuk warga emas. Tekanan kewangan boleh menyebabkan waris warga emas meninggalkannya terdampar di hospital atau menyerahkannya ke pusat-pusat jagaan dalam komuniti. Sekiranya terpaksa menjaga warga emas, keluarga tidak memberikan penjagaan yang sempurna walaupun tinggal bersama keluarga.

\subsection{Cabaran dalam Penuaan Aktif}

\subsubsection{Beban Penyakit Berganda}

Cabaran penuaan penduduk adalah wujud dalam peringkat global, nasional dan tempatan. Bagi mengatasi masalah ini memerlukan perancangan inovatif dan penggubalan dasar mampan di negara maju dan di negara-negara dalam sedang membangun. Di kebanyakan negara maju, perubahan corak hidup dan bekerja akan mempengaruhi perubahan corak penyakit yang dihidapi oleh seseorang warga emas apabila terdapat perbezaan yang ketara kehidupan persaraan dengan dahulu. Beban penyakit berganda ini sudah mereda kekurangan sumber sehingga had dan ini akan menyebabkan bebanan bagi sistem kesihatan dalam negara bagi menyelesaikan isu ini. Berita Harian Malaysia (2015), ketidakseimbangan dalam peningkatan warga tua yang tidak bekerja berbanding dengan golongan penduduk yang aktif bekerja akan menyebabkan kos perbelanjaan pencen serta perubatan dan penjagaan meningkat. 
Sokongan untuk penyelidikan yang berkaitan adalah sangat diperlukan untuk negaranegara yang kurang maju. Pada masa ini, negara berpendapatan rendah dan sederhana mempunyai 85 peratus populasi dunia dan mencecah 92 peratus penyakit membebankan, tetapi hanya 10 peratus perbelanjaan penyelidikan kesihatan dunia dibelanjakan (WHO, 2000).

\subsubsection{Penurunan Kemampuan Dan Keupayaan Fizikal}

Di kedua-dua negara membangun ataupun maju, penyakit kronik adalah ketara dan membawa kepada penyebab kecacatan dan penurunan kualiti hidup. Kebebasan warga emas terancam apabila kecacatan fizikal atau mental menjadikannya sukar menjalankan aktiviti kehidupan seharian. Apabila usia semakin lanjut, warga emas cenderung menghadapi halangan tambahan yang berkaitan dengan proses penuaan. Tahap kecacatan fizikal kognitif bertambah serius seiring dengan bertambahnya usia. Warga emas yang mencecah 80 tahun dan ke atas mengalami penurunan keupayaan fizikal yang paling tinggi. Kehilangan keupayaan fizikal warga emas berkaitan dengan tingkah laku seseorang dalam pengamalan gaya hidup sihat. Pengamalan tingkah laku gaya hidup positif seperti tidak merokok, melakukan senaman atau aktiviti fizikal secara berskala dapat mengurangkan risiko seseorang untuk serangan penyakit sakit jantung dan penyakit kronik yang lain.

\subsubsection{Memberi Penjagaan Kepada Warga Emas}

Seiring bertambahnya usia, salah satu masalah terbesar dalam dasar kesihatan adalah mencapai keseimbangan antara sokongan untuk rawatan diri (penjagaan kendiri), sokongan tidak formal (penjagaan dari ahli keluarga dan rakan) dan penjagaan formal (perkhidmatan kesihatan dan sosial). Penjagaan formal merangkumi kedua-dua penjagaan kesihatan primer (dihantar kebanyakannya di peringkat komuniti) dan institusi jagaan (sama ada di hospital atau rumah jagaan). Walaupun jelas bahawa sebahagian besar perawatan yang diperlukan oleh individu disediakan oleh mereka sendiri atau mereka pengasuh tidak formal, kebanyakan negara memberikannya sumber kewangan secara terbalik, iaitu yang terbesar bahagian perbelanjaan adalah untuk penjagaan institusi. Penjagaan formal melalui perkhidmatan kesihatan dan sistem sosial perlu diakses oleh semua orang. Kebanyakan negara, warga emas yang miskin dan yang tinggal di kawasan luar bandar mempunyai pengaksesan yang terhad ke rawatan kesihatan yang diperlukan. Penurunan sokongan untuk akses kepada perkhidmatan penjagaan kesihatan primer telah meningkatkan beban kewangan dan tekanan antara warga emas dan keluarga mereka (United Nations Economic Commission for Europe, UNECE, 2017).

\subsubsection{Feminisasi dari Penuaan}

Wanita hidup lebih lama daripada lelaki hampir di mana-mana negara sahaja termasuk Malaysia. Ini ditunjukkan jumlah populasi wanita dalam nisbah yang lebih tinggi berbanding lelaki dalam kumpulan usia yang lebih tua. Statistik Jabatan Perangkaan Malaysia (2018), jangka hayat bagi lelaki warga emas adalah 79.8 tahun manakala warga emas wanita adalah 82.1 tahun. Sementara wanita mempunyai kelebihan jangka hayat, mereka lebih banyak kemungkinan daripada lelaki mengalami kekerasan dalam rumah tangga dan diskriminasi dalam akses kepada pendidikan, pendapatan, makanan, pekerjaan yang bermakna, kesihatan penjagaan, warisan, langkah keselamatan sosial dan kuasa politik. Ini telah menunjukkan bahawa wanita lebih terdedah mengalami 
kemiskinan dan penderitaan kekurangan upaya kerana status wanita lebih rendah daripada golongan lelaki kerana kesihatan wanita yang lebih tua sering diabaikan.

\subsubsection{Ekonomi bagi Populasi Warga Emas}

Pembuat dasar bimbang terhadap trend peningkatan warga emas dalam kadaran yang cepat menyebabkan institusi kerajaan tidak dapat menampung kos keselamatan sosial dan penjagaan kesihatan bagi warga emas untuk memelihara kebajikan mereka. Peningkatan kos rawatan kesihatan adalah berkaitan dengan ketidakcekapan dalam penyediaan pusat penjagaan dan hospital, sistem pembayaran yang mendorong pesakit tinggal sepanjang umur hidup di hospital dan penggunaan teknologi yang kos tinggi. Keprihatinan utama yang kedua bagi pembuat dasar adalah permintaan warga emas dalam menggunakan sistem keselamatan sosial. Penuaan global memerlukan pemerintah dan sektor swasta untuk menangani cabaran untuk sistem keselamatan sosial dan pencen. Pendekatan yang seimbang untuk penyediaan sosial tujuan perlindungan dan ekonomi menunjukkan bahawa masyarakat yang sanggup merancang mampu bertahan waktu menjadi tua. Dasar pasaran buruh (misalnya, insentif untuk persaraan awal dan amalan persaraan wajib) mempunyai kesan yang lebih dramatik terhadap kemampuan negara untuk menyediakan perlindungan sosial pada usia tua. Tujuannya adalah untuk memastikan taraf hidup warga emas pada waktu selepas persaraan dapat dikekalkan. Warga emas perlu membuat perancangan bermula dari waktu muda dengan menyimpan sejumlah wang untuk kegunaan semasa usia tua agar tidak menerima kesan yang teruk waktu menghadapi kekangan dalam kehidupan khususnya bagi warga emas yang tiada penemanan anak di sisi disebabkan tujuan pekerjaan, pembinaan keluarga baru dan keperluan pendidikan. Cabaran kewangan timbul terutamanya kepada mereka yang tidak mempunyai simpanan atau pencen yang mencukupi untuk menyara hari tua mereka. Di Malaysia masalah yang berkaitan dengan kecukupan simpanan untuk persaraan dalam kalangan mereka yang bakal bersara boleh dianggap membimbangkan. Keperluan tempat tinggal bagi yang menyewa, makan minum serta perubatan adalah antara beberapa perkara asas yang memerlukan peruntukan kos yang besar. Dalam konteks semasa, masalah kewangan pada usia emas boleh menambah tekanan kepada golongan berusia kerana kekangan ini boleh menyebabkan mereka berhadapan dengan kesukaran dalam menghabiskan sisa-sisa riwayat mereka.

\subsubsection{Membentuk Paradigma Baru}

Secara tradisinya, usia tua dikaitkan dengan persaraan, penyakit dan tanggungan. Dasar dan program yang tersekat dalam paradigma ini tidak menggambarkan realiti. Sesungguhnya, kebanyakan warga emas kekal bebas bergerak sehingga sangat tua umur terutama di negara membangun, banyak warga emas yang berumur lebih dari 60 tahun terus mengambil bahagian dalam tenaga buruh. Warga emas yang aktif dalam sektor pekerjaan tidak rasmi misalnya, kerja domestik dan aktiviti kecil serta bekerja sendiri walaupun ini sering tidak dikenali di statistik pasaran buruh. Di semua negara, aktiviti sukarela yang dilakukan warga emas memberikan sumbangan ekonomi dan sosial yang penting kepada masyarakat. Inilah masanya untuk paradigma baru yang memandang warga emas aktif dalam usia yang bersepadu antara masyarakat dan penyumbang aktif sebagai serta penerima faedah dalam pembangunan. Kehidupan warga emas berhadapan dengan beban penyakit akhir hayat global. Oleh itu, rawatan kendiri adalah langkah yang paling mudah dan kurang bergantungan kepada pihak lain. Rawatan diri pada peringkat gerontologi merujuk kepada tingkah laku individu yang berdasarkan 
teori yang memungkinkan orang dewasa untuk membuat keputusan dan bertindak atas pencegahan, diagnosis dan rawatan penyakitnya, serta pemeliharaan kesihatan dan bagi memaksimumkan kualiti hidup, manakala jikalau menurut konteks sosiobudaya, menggunakan jaringan sosial formal dan tidak formal secara optimum semasa penuaan dapat membantu seseorang dalam penjagaan kesihatan perseorangan (Mendoza-Nunez et al., 2009). Menurut Partridge et al. (2018), perubahan gaya hidup termasuk peningkatan senaman dan pengurangan pengambilan makanan yang tinggi kolestrol dapat mempertingkatkan tahap kesihatan.

\section{Perbincangan Kajian}

Penuaan aktif merujuk kepada pemberdayaan warga emas dalam bidang biologi, psikologi, dan sosial, memahami pemberdayaan sebagai promosi diri, kebebasan, dan keyakinan diri individu, serta haknya terhadap cara hidup yang bermartabat, kemampuan untuk membela hak sendiri dan bebas (Mendoza et al., 2009). Model yang dicadangkan merangkumi enam kumpulan penentu yang masing-masing merangkumi beberapa aspek: (1) perkhidmatan kesihatan dan sosial; (2) tingkah laku; (3) peribadi; (4) persekitaran fizikal; (5) sosial; (6) ekonomi yang tertanam dalam konteks budaya dan jantina dengan cadangan dasar kesihatan untuk warga emas, untuk dilaksanakan melalui rancangan kesihatan nasional di seluruh dunia. Perkhidmatan kesihatan dan sosial yang dimaksudkan adalah usaha pihak berkepentingan seperti Badan bukan kerajaan (NGO) dan pembuat dasar dalam mempromosikan kesedaran tentang kesihatan, prosedur dalam pencegahan penyakit melalui penjagaan kebersihan kendiri, perkhidmatan kesihatan tersedia, penjagaan berterusan terhadap kognitif dan kesihatan mental.

Ann Bowling (2007) menyatakan bahawa dalam persepsi warga emas terhadap konsep penuaan aktif., pengekalan kesihatan dan fungsi fizikal, aktiviti riadah dan sosial, aktiviti kaunseling mental adalah aspek yang boleh diukur adakah warga emas tersebut aktif. Penglibatan sosial dilihat penting dalam konteks ini. Penyertaan warga emas dalam sesuatu aktiviti mampu mengukuhkan ketahanan interaksi sosial mereka agar masih mampu berkomunikasi dengan komuniti persekitaran yang bertindak sebagai sokongan sosial tidak formal. Faktor persekitaran juga merangkumi persekitaran alam disokong oleh Anner et al. (2012) pengaruh alam sekitar terhadap kesihatan dan penyertaan aktiviti warga tua merupakan elemen dalam penentuan penuaan aktif dalam kalangan warga emas. Penemuan mengenal pasti sokongan untuk pengaruh peribadi dan persekitaran terhadap kesihatan dan penyertaan aktiviti pada kemudian hari oleh warga emas. Pengaruh peribadi yang dilaporkan termasuk etnik dan norma budaya, tenaga dan motivasi, jantina, umur, pendidikan, warisan genetik, keberkesanan diri dan keadaan kewangan peribadi. Pengaruh alam sekitar yang dilaporkan terhadap penyertaan aktiviti termasuk iklim, tahap pencemaran, lampu jalan, keadaan lalu lintas, kebolehcapaian dan kesesuaian perkhidmatan dan kemudahan, keadaan sosio-ekonomi, estetika, infrastruktur pejalan kaki, kehidupan masyarakat, pendedahan kepada tingkah laku antisosial, penyertaan rangkaian sosial, alam sekitar kemerosotan, tahap urbanisme, pendedahan kepada persekitaran semula jadi, kebiasaan dengan persekitaran tempatan dan lain-lain.

Penggunaan strategi digital untuk membolehkan penuaan aktif adalah bidang penyelidikan antarabangsa yang menarik dan pelbagai. Kajian ini telah menyerlahkan halangan kepada penyelidikan dan kajian mendalam mengenai intervensi penuaan aktif berasaskan e-kesihatan. Terdapat kekurangan konsensus mengenai ukuran hasil pilihan, 
atau sememangnya strategi intervensi yang paling berkesan. Terdapat percanggahan antara elemen teknikal penyelidikan ini dan intervensi berasaskan percubaan klinikal yang lebih tradisional. Mendayakan penuaan aktif yang berjaya adalah keutamaan antarabangsa untuk menghadapi cabaran peningkatan jangka hayat. Strategi digital, seperti teleperubatan dan e-kesihatan, menawarkan potensi untuk menyampaikan penuaan aktif dengan cara yang kos efektif.

Tingkah laku pula menerangkan pengamalan sikap dan gaya hidup yang boleh mendatangkan keburukan seperti merokok dan pengambilan minuman keras waktu usia berlanjutan manakala gaya hidup yang sihat seperti melakukan kegiatan kesihatan secara berskala, pengambilan pemakanan yang seimbang dan menitikberatkan kesihatan mulut (oral health). Carstairs dan Keon (2007) penglibatan diri dalam pelbagai aktiviti yang dapat mengekalkan gaya hidup sihat harus digalakkan sejak kecil lagi. Wacana penuaan aktif bukan sahaja terpakai kepada warga emas, tetapi kepada semua peringkat umur (Carstairs \& Keon, 2007). Penglibatan atau penerimaan gerakan sukarelawan mampu melibatkan warga emas yang lemah dapat mempertingkatkan kesejahteraan psikologi mereka kerana berasa diri mereka dihargai.

Penentuan peribadi seperti unsur biologi, genetik dan juga faktor psikologi seseorang warga emas. Warga emas pada masa kini kebanyakan mengalami empty nest dimana Menteri Kementerian Pembangunan Wanita, Keluarga dan Masyarakat menyatakan bahawa hampir 23 peratus atau 538,000 orang daripada 2.4 juta warga emas di negara ini mengalami sindrom sarang kosong iaitu empty nest (rasa kesunyian dan sedih) akibat tinggal bersendirian dan jauh daripada anak-anak.

Warga emas yang mencapai penuaan aktif memerlukan sistem sokongan sosial yang mewujudkan integrasi mereka dalam sesuatu komuniti agar dapat kekal aktif dalam rangkaian sosial persekitaran. Persekitaran fizikal memainkan peranan yang penting dalam memastikan warga menua secara aktif contohnya persekitaran yang mesra dengan keperluan warga emas seperti pembinaan kemudahan dan infrastruktur yang menjadi keperluan seperti kedai runcit, pasar, taman rekreasi, hospital dan klinik kesihatan. Rumah yang selamat juga akan memastikan warga emas hidup dengan lega dan menikmati kehidupan mereka tanpa merisaukan keselamatan kendiri di penempatan mereka. Isu jatuh dalam kalangan warga emas merupakan konflik yang kerap berlaku kerana penurunan keupayaan fizikal dan status isirumah yang tidak tinggal bersama penjaga seperti anak dan saudara mara. Oleh itu, isu kemalangan dalam kalangan warga emas perlu dipandang serius kerana mampu memberi kesan yang kritikal kepada tahap kesihatan dan kemampuan mobiliti warga emas pada waktu kelak. Faktor sosial merangkumi sokongan sosial, keganasan dan penderaan dan pendidikan dapat mempengaruhi keaktifan warga emas dan memberi impak dalam penglibatan diri dalam komuniti setempat. Keadaan ekonomi warga emas juga menentukan kesejahteraan warga emas untuk kekal aktif kerana merupakan sumber untuk menyokong keperluan dan kehendak mereka dalam kehidupan. Jaminan sosial kebiasaannya diberi sumbangan daripada pihak kebajikan dan pembuat dasar dalam melaksanakan insentif dan bantuan kewangan kepada warga emas seperti bantuan kewangan warga emas, potongan diskaun bagi perkhidmatan pengangkutan awam, penyediaan pusat penjagaan warga emas dan sebagainya. 


\section{Kesimpulan}

Warga emas perlu aktif semasa penuaan bagi menjamin kesejahteraan selepas bersara kerana masih mampu memberi sumbangan sama ada dalam sektor formal atau informal. Keperluan warga emas perlu diambil kira dalam perancangan polisi negara agar dapat menghadapi kebanjiran populasi pada masa akan datang. Warga emas berperanan sebagai aset dan khazanah negara yang perlu dipelihara agar mampu menjana keseimbangan pembangunan modal insan secara menyeluruh tanpa mengira struktur umur. Warga emas yang aktif dapat menyingkirkan diri daripada kemurungan dan kesan daripada keuzuran kerana mampu memanfaatkan masa lapangannya secara optimum.

\section{Penghargaan (Acknowledgement)}

Ribuan terima kasih diucapkan kepada Kementerian Pengajian Tinggi (KPT) kerana telah membekalkan dana penyelidikan di bawah Geran FRG 0544-2020/SS0/UMS/02/3 untuk menyokong dalam menyempurnakan kajian ini.

\section{Kewangan (Funding)}

Geran FRG 0544-2020/SS0/UMS/02/3

\section{Konflik Kepentingan (Conflict of Interests)}

Para penulis tidak mempunyai konflik kepentingan.

\section{Rujukan}

Ahmad Bahuri, Nor H., Hussein Rizal, Hazreen Abdul Majid, Mas A. Said, \& Tin T. Su. (2021). Development of the Active Ageing Awareness Questionnaire in Malaysia. Healthcare, 9(5), 499.

Ann Bowling. (2007). Enhancing later life: How older people perceive active ageing? Ageing \& Mental, 12(8).

Annear, M. et al. (2012). Environmental influences on healthy and active ageing: a systematic review. Ageing and Society, 34 (4), 590-622. doi:10.1017/S0144686X1200116X

Astro Awani. (2021). Malaysia bersedia hadapi status negara tua. Diakses pada 1 Oktober 2021 daripada laman web: https://www.astroawani.com/beritamalaysia/malaysia-bersedia-hadapi-status-negara-tua-292513

Barca, M.L., Engedal, K.; Laks, J. \& Selbaek, G. (2011). Quality of life among elderly patients with dementia in institutions. Dementia and Geriatric Cognitive Disorders, 31, 435-442.

Berita Harian Malaysia. (2015 April 3). Cabaran negara tangani masyarakat warga tua. https://www.malaysiakini.com/news/294177

Bongaarts, J. \& Zimmer, Z. (2002). Living Arrangements of Older Adults in the Developing World: An Analysis of Demographic and Health Survey Household Surveys, The Journals of Gerontology, 57(3), S145-S157, https://doi.org/10.1093/geronb/57.3.S145 
Bravo V.T.F., Ventura, R.U., Brandt, C.T., Sarteschi, C. \& Ventura, M.C. (2012). Visual impairment impact on the quality of life of the elderly population that uses the public health care system from the western countryside of Pernambuco State, Brazil. Arq. Bras. Oftalmol, 75, 161-165.

Carp, F. M. (1998). Transportation in Ageing Society: Improving Mobility and Safety of Older Persons. https://onlinepubs.trb.org/onlinepubs/sr/sr218v2.pdf

Carstairs, S., \& Keon, W. J. (2007). Embracing the challenge of aging. Ottawa: The Special Senate Committee on Aging.

Daatland, S. (2005). Quality of life and ageing. In M. Johnson (Ed.). The Cambridge handbook of age and ageing : 371-377. Cambridge: Cambridge University Press

de Jong, P. \& Brouwer, A. (2012). Residential Mobility of Older Adults in the Dutch Housing Market: Do Individual Characteristics and Housing Attributes Have an Effect on Mobility? European Spatial Research and Policy, 19(1), 33-47. https://doi.org/10.2478/v10105-012-0004-9

De Luca, K., Wong, A.; Eklund, A., Fernandez, M., Byles, J.E., Parkinson, L., Ferreira, M.L. \& Hartvigsen, J. (2019). Multisite joint pain in older Australian women is associated with poorer psychosocial health and greater medication use. Chiropratic Manual Therapies 27, 8.

Esther, H. K. Y, Sheila Conejos \& Edwin H. W. C. (2016). Social needs of the elderly and active aging in public open spaces in urban renewal. Cities, 52, 114-122.

Fozard, J. L. (1990). Handbook of the Psychology of Ageing. New York: Academic Press.

Goggin, N. L., G.E. Stelmach, \& P. C. Amrchein. (1989). The Effects of Age on Motor Preparation and Restructuring. Bulletin of the Psychonomics Society, 27, 199-202.

Gray, A. (1996). Preventive Medicine. in: Epidemiology in Old Age. Ebrahim S and Kalache A (eds) London: BMJ Publishing Group.

Guralnick, J. M. \& Kaplan, G. (1989). Predictors of healthy aging: prospective evidence from the Almeda County Study. American Journal of Public Health, 79, 703-8.

Hijas-Gómez et al. (2020.). The WHO active ageing pillars and its association with survival: Findings from a population-based study in Spain, Archives of Gerontology and Geriatrics, 90, 104114. https://doi.org/10.1016/j.archger.2020.104114.

Ho, B. K. (2016). Pencegahan Kecederaan: Pencegahan Bahaya Memandu Untuk Warga Emas. Diakses pada 28 Febuari 2021 daripada laman web: http://www.pencegahanbahaya- memandu-untuk-warga-emas https://www.kpwkm.gov.my/kpwkm/uploads/files/Dokumen/Dasar/Dasar\%20 Warga \%20Emas_2011.pdf

Institusi Penyelidikan Penuaan Malaysia. (2017). Persatuan Pembelajaran Sepanjang Hayat Warga Emas U3A KL \& Selangor. Diakses pada 2 oktober 2021 daripada laman web: https://myageing.upm.edu.my/jaringan/industri/persatuan_pembelajaran_sepanj ang_hayat_warga_emas_u3a_kl_selangor-3496?L=bm

Ismail Sulaman. (2019 Januari 27). Kualiti Pendidikan Malaysia antara terbaik di dunia. Sinar Harian. www.sinarharian.com.my/article/9910/KOLUMNIS/PendidikanMalaysia

Jabatan Perangkaan Malaysia. (2018). Older Population (60+) in Malaysia, 1970-2040. https://www.dosm.gov.my/

Kaniz Fatima \& Sara Moridpour. (2018). Measuring Public Transport Accessibility for Elderly. MATEC Web of Conferences. Diakses pada 3 October 2021 daripada laman web: https://doi.org/10.1051/matecconf/2019225590300690

Kementerian Kesihatan Malaysia. (2016). Penuaan aktif. Diakses pada 28 September 2021 daripada: http://www.myhealth.gov.my/penuaan-aktif/ 
Kementerian Kesihatan Malaysia. (2017). Akaun Kesihatan Negara Malaysia. Diakses pada 29 September 2021 daripada laman web: https://www.moh.gov.my/moh/resources/Penerbitan/Penerbitan\%20Utama/M NHA/Laporan_MNHA_Health_Expenditure_Report_1997-2017_03122019.pdf

Kementerian Pembangunan Wanita, Keluarga dan Malaysia. (2011). Dasar Warga Emas Negara.

https://www.kpwkm.gov.my/kpwkm/uploads/files/Dokumen/Dasar/Dasar\%20 Warga\%20Emas_2011.pdf

Kementerian Pembangunan Wanita, Keluarga dan Masyarakat. (2011). Dasar Warga Emas Negara. Diakses pada 28 September 2021 daripada:

Kementerian Pembangunan Wanita, Keluarga dan Masyarakat. (2017). Perangkaan wanita, keluarga dan masyarakat. Putrajaya; Kementerian Pembangunan Wanita Keluargadan Masyarakat. Diakses pada 2 Disember 2020 daripada laman web: www.kpwkm.gov.my.

Kirkwood, T. (1996). Mechanisms of Ageing. In Epidemiology in Old Age. Ebrahim S and Kalache A (eds) London: BMJ Publishing Group.

Lai, W. S. (2020). Isu penuaan penduduk wajar diberi perhatian. Berita Harian. Diakses pada 29 September 2021 daripada laman web: https://www.bharian.com.my/rencana/komentar/2020/11/759896/isupenuaan-penduduk-wajar-diberi-perhatian

Luciana, E. (2016). Peranan UN Women dalam Penghapusan Diskriminasi terhadap Kaum Perempuan di India. Universiti Pasundan. Bandung Indonesia.

Mario Ulises et al. (2021). Frailty among middle-aged and older Canadians: population norms for the frailty index using the Canadian Longitudinal Study on Aging. Age and Ageing, 50(2), 447-456.

Mendoza-Núñez et al. (2009). Implementation of an active aging model in Mexico for prevention and control of chronic diseases in the elderly. BMC Geriatr 9, 40.

Micah, P. et al. (2015). Guidance for conducting systematic scoping reviews. International Journal of Evidence-Based Healthcare, 13(3).

Moses, 0. 0. \& Oluwole Aloba. (2014). Mobility characteristics of the elderly and their associated level of satisfaction with transport services in Osogbo, Southwestern Nigeria. Transport Policy 35, 105-116

Mstar (2017 20ktober 27). Celik Huruf, Malaysia Di Tangga Ke-53. Star Media Group Berhad. https://www.mstar.com.my/lokal/semasa/2017/10/23/celik-huruf

Nik Norliati Fitri Md Nor. (2018). Trend Penuaan Penduduk: Satu Sorotan Karya. Journal of Social Science and Humanities, 13(2), 116-130.

Noraida Ibrahim, Zarina Mat Saad \& Fatimah Zailly Ahmad Ramly. (2014). Dasar Warga Emas Negara dan Pusat Aktiviti Warga emas di Malaysia. ISDC2014 Conference. 1213 August 2014.

Nur Syakiran Akmal Ismail , Norehan Abdullah, Kalthum Hassan, Shamzaeffa Samsudin, Ummu Atiyah Ahmad Zakuan, Rohana Yusof \& Nurzalyna Mohamed Zaki. (2017). Kesejahteraan hidup warga emas: Perancangan berasaskan gender. Malaysia Journal of Society and Space, 13(3), 75-85.

OECD. (2017). Incomes of older people. In Pensions at a Glance 2017: OECD and G20 Indicators, OECD Publishing, Paris. https://doi.org/10.1787/pension_glance-201726-en

Pala, J. (2005). Population Ageing Trends in Malaysia. Kuala Lumpur.

Pandey, S. (2018). Factors Contributing of Ageing: Factors in Ageing. Handbook of Research on Geriatric Health, Treatment, and Care: 18.

Partridge, L., Deelen, J. \& Slagboom, P.E. (2018). Facing up to the global challenges of ageing. Nature, 561, 45-56. 
Portegijs, E. et al. (2022). Impact of mobility restrictions on active aging; cross-sectional associations and longitudinal changes parallel to COVID-19 restrictions. Archives of Gerontology and Geriatrics, 98, 104522.

Rantanen. T., Portegijs. E., . Kokko. K, Rantakokko. M, Tormakangas T, Saajanaho. M. (2019). Developing an Assessment Method of Active Aging: University of Jyvaskyla Active Aging Scale. Journal of Aging and Health, 31, 1002-1024

Robbins, T. D. et al. (2018). E-health for active ageing; A systematic review, Maturitas, 114, 34-40,

Rocío Fernández-Ballesteros, Jean Marie Robine, Alan Walker \& Alex Kalache. (2013). Active Aging: A Global Goal. Current Gerontology and Geriatrics Research.

Said, E. A. (2017). Health-related quality of life in elderly hearing aid users vs. non-users. Egyptian Journal Ear Nose Throat Allied Sci, 18, 271-279.

Saraswat, L., Rehman, H., Omar, M., Cody JD., Aluko, P. \& Glazener, C.M.A. (2020). Traditional suburethral sling operations for urinary incontinence in women. Cochrane Database of Systematic Reviews, 1.

Sarin Johani, Khadijah Alavi, Mohd Suhaimi Mohamad. (2018). Perbandingan Tahap Kualiti Hidup Bagi Warga Emas Yang Mendapatkan Perkhidmatan Di Pusat Aktiviti Warga Emas (PAWE) Di Kawasan Bandar Dan Luar Bandar. Jurnal Psikologi Malaysia, 32(3), 82-90.

Sierra-Correa, Paula Cristina \& Cantera Kintz, Jaime Ricardo. (2015). Ecosystem-based adaptation for improving coastal planning for sea-level rise: A systematic review for mangrove coasts. Marine Policy, Elsevier, 51(C), 385-393.

Siti Nadira Ahmad Rozlan Shah, Rosmadi Fauzi \& Jamilah Mohamad. (2015). Membina model indeks kesejahteraan hidup penduduk bagi Semenanjung Malaysia. Malaysian Journal of Society and Space, 11(4),87-96.

Siti Zaila Husin \& Khadijah Alavi. (2016). Kerja Sosial di Hospital: Meneroka Pengabaian Dalam Kalangan Pesakit Warga Emas. Journal of Social Science and Humanities, $4(2), 462-484$

Smits, C. H., Deeg, D. M., \& Schmand, B. (1999). Cognitive functioning and health as determinants of mortality in an older population. American Journal Epidemiology, 150(9)978-86.

Stenner, A., McFarquhar, T., \& Bowling, A. (2011). Older people and active ageing: Subjective aspects of ageing actively. Journal of Health Psychology, 16, 467-477.

Stewart, F. \& J. Yermo .(2009).Pensions in Africa. OECD Working Papers on Insurance and Private Pensions, No. 30, OECD publishing. doi:10.1787/227444006716

Townsend, P. (2007). Using human rights to defeat ageism: dealing with policy-induced ' structured dependency'. In M. Bernard \& T. Scharf (eds.) Critical perspectives on ag eing societies. Cambridge: Polity press.

Tricco, A. C. et al. (2018). PRISMA Extension for Scoping Reviews (PRISMAScR): Checklist and Explanation. Ann International Medication, 169, 467-473

United Nation. (2021). Projection of population of Malaysia. Diakses pada 29 September 2021 daripada laman web: https://www.macrotrends.net/countries/MYS/malaysia/life-expectancy

United Nations Economic Commission for Europe (UNECE). (2017). Policy briefs on Ageing (2009 - 2021). Diakses pada 15 Januari 2021 daripada laman web: https://unece.org/fileadmin/DAM/pau/age/Policy_briefs/ECE-WG1-25.pdf

United State Department of Transportations (USDOT). (1997). Improving Transportation for a Maturing Society.DOT-P10-97-01 Office of the Assistant Secretary for Transportation Policy.

Utusan Borneo Online. (2018 Ogos 13). Warga emas perlu amal gaya hidup sihat. https://www.utusanborneo.com.my/2018/08/13/warga-emas-perlu-amal-gayahidup-sihat 
Walker, A., \& Foster, L. (2013). Active ageing: Rhetoric, theory and practice. In R. Ervik \& T. Skogedal Lindén (Eds.). The making of aging policy: Theory and practice in Europe (pp. 27-53). Cheltenham: Edward Elgar.

Walker, A., \& Maltby, T. (2012). Active aging: A strategic policy solution to demographic ageing in the EuropeanUnion. International Journal of Social Welfare, 21, S117S130.

World Health Organization (WHO). (1994). Health for all: Updated targets. Diakses pada 28 September 2021 daripada laman web:https://www.euro.who.int/_data/assets/pdf_file/0006/109779/WA_540_G A1_85TA.pdf

World Health Organization (WHO). (1998) Growing Older. Staying Well. Ageing and Physical Activity in Everyday Life. Prepared by Heikkinen RL. Geneva: World Health Organization.

World Health Organization (WHO). (2002). Active ageing : a policy framework. Diakses pada 28 September 2021 daripada laman web: https://apps.who.int/iris/handle/10665/67215

World Health Organization. (2000) (WHO). Home-Based and Long-term Care. Report of a WHO Study Group. WHO Technical Report Series 898. Geneva: World Health Organization: 